\title{
ARTICLES
}

\section{Compelling Compromise: Canada chooses Conciliation over Arbitration 1900-1907}

\author{
Jeremy Webber
}

... for the most part it [the departmental correspondence] was well answered by Harper, but there were one or two points in which I thought he showed his own personal foeling or point of view to [sic] strongly. One has to conceal these, and evade rather then combat to save strife. (W.L. Meckenzie King, federal Deputy Minister of Labour, speaking of his assistant's handling of the depertmental correspondence, 14 August 1901 $^{1}$ )

\section{Introduction}

AT LEAST SINCE THE TURN of the 20th century, when Ottawa initiated a policy of intervention in labour disputes based on conciliation, Canadian labour policy has been marked by an acute tension between the state's drive to prevent industrial conflict on the one hand, and its reluctance to specify terms of employment on the other. Canadian governments have tried to create structures which would produce the fact of settlement while leaving the content of settlement to the bargaining power of the parties. They have searched, one might say, for a way to compel compromise. $^{2}$

\footnotetext{
${ }^{1} \mathrm{King}$ Diary, 14 August 1901, National Archives of Canada (NAC), MG $26 \mathrm{~J} 13$.

${ }^{2} A$ note on terminology: I use "settlement" to mean any decision not to strike, whether a formal agreement results or not. This accords with Ottawa's use of the term, its only interest being the prevention of work stoppages.
}

Jeremy Webber, "Compelling Compromise: Canada Chooses Conciliation Over Arbitration 1900-1907," Labow/Le Travail 28 (Fall 1991), 15-57. 
Thus, during the heady days of World War II, Otawa long resisted pressure for legislation requiring employers to recognize unions, trying instead to prevent recognition strikes through protracted mediation. ${ }^{3}$ In 1944 Otawa did pass Order in Council PC 1003 (17 February 1944), which obliged employers to bargain with unions representing the majority of their employees. Yet even in the postwar era, policymakers have struggled to reconcile the pursuit of industrial peace with the commitment to a voluntaristic labour relations system: the failure of compulsory recognition to produce effective negotiations led labour boards to flesh out the duty to bargain; the continued inability of unions to achieve collective agreements has prompted several jurisdictions to experiment with first-contract arbitration; and now concerns are expressed that many unions are unable to renew agreements reached by that means. The tension between industrial peace and the deference to consent remains."

This paper explores the foundations of this central tension in Canadian labour policy. It investigates that policy's development in the crucial years between 1900 and 1907, attempting to determine why Ottawa rejected direct state involvement in the fixing of terms of employment, opting instead for accommodation as the leitmotif of the new regime. Through the legislative and administrative experimentation of those years, Canadian policymakers developed the brand of governmentsponsored intervention which was to form the core of Ottawa's labour policy for the next four decades, and which continues to occupy a prominent place in Canadian labour relations.

Between 1900 and 1907 , this policy took three successive statutory forms. The first was The Conciliation Act, SC 1900, c. 24, which ostensibly concerned the

In incustrial relations literature "arbitration," "conciliation," and "mediation" have taken on precise and highly-technical meanings (often too precise given the practice of intervention). Their meanings were much more flexible during the period studied here: "arbitration," for example, was used to mean anything from collective bargaining with no third-party involvement to binding third-party adjudication. This paper will use "conciliation" and "mediation" interchangeably to refer to thind-party intervention that does not result in a binding award. "Arbitration" will be used to describe intervention intended to produce a binding award. For simplicity's sake I will also use this terminology in references to turn-of-the-century sources, translating the original terms when necessary.

${ }^{3}$ See J. Webber, "The Malaise of Compulsory Conciliation: Strike Prevention in Canada During World War II," Labour/Le Travail, 15 (1985), 57-88.

The tendency to prefer compromise over coercion has even been evident in those areas of labour law where norms have been enacted. See, for example, Eric Tucker, "Making the Workplace 'Safe' in Capitalism: The Enforcement of Factory Legislation in Nineteenth Century Ontario," Labour/Le Travail, 21 (1988), 45-85; Margaret E. McCallum, "Keeping Women in Their Place: The Minimum Wage in Canada, 1910-25," Labour/Le Travail, 17 (1986), 29-56; Paul Weiler, Reconcilable Differences: New Directions in Canadian Labour Law (Toronto 1980), 296-8; and the handling of the Alien Labour Act, SC 1897, c. 11. violation described below. 
registration of voluntarily-established conciliation boards, but was used in practice to justify mediation by individual departmental officers. This was followed by The Railway Labour Disputes Act, SC 1903, c. 55, which provided for the investigation of railway disputes by boards made up of one nominee of the employer, one of the employees, with the chair chosen by the first two. The last was The Industrial Disputes Investigation Act, SC 1907, c. 20 (the "IDIA"), which extended the principle of the 1903 statute to "public utilities" and banned strikes in those undertakings prior to conciliation."

In each of these three incamations, the essential strategy was the same. Each searched for a way to inject a third party into an industrial dispute, preferably before the conflict reached the stage of a strike or bockout. Each contemplated that the conciliator or ad-hoc board, clothed with a measure of governmental authority, would interview the parties, urging them to settle their differences through compromise. If no settlement was achieved, the third party could issue a public report making non-binding recommendations. This was to be used only as a last resort, however. Throughout the intervention (and indeed following the conciliator's report), the government sought agreement through mutual concession and quiet compromise.

In opting for a regime based on conciliation, the Canadian government deliberately rejected the compulsory-arbitration models of New Zealand, New South Wales, and the Australian Commonwealth. ${ }^{6}$ On a number of occasions Canadian officials and cabinet members, up to and including the Prime Minister, Sir Wilfrid Laurier, toyed with the idea of adopting arbitration. In 1902, the government introduced a bill (allowed to die on the order paper) providing for arbitration on the railways. At various times during the decade, individuals and associations ranging from the Trades and Labor Congress of Canada (before 1902) to the Union of Canadian Municipalities, the Montreal Builders' Exchange, and the President of the Canadian Pacific Railway, all lobbied for arbitration. Between 1900 and 1907 at least ten Members of Parliament - many representing labour constituencies and several identified with the government - declared their support for the judicial settlement of disputes. During the debate on the IDIA, Opposition Leader Robert $\mathrm{L}$. Borden argued that a House committee should investigate the feasibility of compulsory arbitration (although he stopped short of proposing its adoption).

\footnotetext{
'In 1906, the first two acts were consolidated to form The Conciliation and Labour Act, RSC 1906, c. 96.

'The Industrial Conciliation and Arbitration Act, SNZ 1894, No. 14; Industrial Arbitration Act, SNSW 1901, No. 59; Commonwealth Conciliation and Arbitration Act, S. Australia 1904, No. 13.

'Consideration of arbitration by Deputy Minister King or members of cabinet, King Diary, 15 November 1900, 30 September 1901, and 14 May 1903, NAC, MG 26, J 13; King to F. Challaye, 11 November 1903, King papers, NAC, MG 26, J 1, vol. 3, 2916. The Report of the Royal Commission on Industrial Disputes in the Province of British Columbia, Canadn
} 
This paper begins by reviewing the formation of the government's policy during the first years of this century. It will not attempt a complete narrative. Extensive discussions of the legislative evolution and administrative practice exist elsewhere." It will focus on two themes which have not been fully developed in previous work, but which are essential to understanding the objectives and motivation underlying the regime.

The first theme is the remarkable consistency in practice under diverse statutory structures. A number of commentators, seduced by highly-misleading official descriptions of the regime, have suggested that the statutes - particularly the IDIA - were designed to promote industrial peace by exposing labour disputes to public scrutiny: when a strike was threatened, a board would investigate, laying the facts before the public; thus informed, public opinion would force the parties to be reasonable.' But this official story never accurately described the aim or experience under the acts. The essential nature of the intervention remained the same no matter what the statutory authority. Legislation was passed to make conciliation more effective, not replace it with arbitration by public opinion.

The second theme concerns the role of that eminently-fascinating figure, W.L. Mackenzie King, in the development of the conciliation policy. Most accounts of

Sessional paper No. 36a, 1903 (of which King was secretary) recommended that the Governor in Council be empowered to order arbitration in "public service undertakings." In 1910, Laurier asked King (now Minister of Labour) to consider arbitration once more, King to G.P. Graham, 8 August 1910, King papers, NAC, MG 26, J 1, 12902. The text of the 1902 arbitration bill was published in The Labour Gazette, 2 (1902), 769-79. For the position of the Trades and Labor Congress, see below, note 59. For the Union of Canadian Municipalities, The Labowr Gazette, 3 (1902), 273. For the Builders' Exchange, King papers, NAC, MG 26, J 4, vol. 14, file 83, C9642. For the CPR President, Shaughnessy to Laurier, 4 February 1902, Laurier papers, NAC, MG 26, G, vol. 222, 62541-2 and James J. Atherton. "The Department of Labour and Industrial Relations, 1900-1911," MA thesis, Carleton University 1972, 176-7. MPs speaking in favour of arbitration included Arthur Puttee, Ralph Smith, H.J. Logan, William Ross, W.A. Galliher, D. Henderson, J. Herron, Henri Bourassa, T.S. Sproule, and Armand Lavergne. For Borden's comments see, Canada, House of Commons, Debates, 9 January 1907, 1150ff.

'Pall Craven, 'An Impartial Umpire' : Industrial Relations and the Canadian State 1900. 1911 (Toronto 1980); Ben M. Selekman, Postponing Strikes (New York 1927).

${ }^{9}$ H.D. Woods, "Canadian Collective Bargaining and Dispute Setrlement Policy: An Appraisal," Canadian Journal of Economics and Political Science, 21 (1955), 455; H.A. Logan, State Intervention and Assistance in Collective Bargaining (Toronto 1956); Stuart Marshall Jamicson, Times of Trouble: Labour Unrest and Industrial Conflict in Canada, 1900-66 (Ottawa 1968), 128-9; Reginald Whitaker, "The Liberal Corporatist Ideas of Mackenzie King," LabourlLe Travailleur, 2 (1977), 152. For arguments to the contrary, see Ben M. Selekman, Postponing Strikes (New York 1927), 16 and 102-13, Atherton, "Department of Labour," 220-1, and Paul Craven, "King and Context: A Reply to Whitaker," Labour/Le Travaillewr. 4 (1979), 176-7 and 'An Impartial Umpire' (although as will become clear, Craven's focus on King ignores broader continuities). 
the policy have focused on King. ${ }^{10}$ King was deputy minister of labour from 1900 to 1908, and minister from 1908 until the defeat of the Laurier Liberals in 1911. Soon after his arrival in Ottawa in 1900, he became the government's chief conciliator and remained responsible for the policy throughout the period examined here. In the winter of 1906-07, he drafted the most influential of the statutes, the IDIA. But although King's contribution was considerable, he did not determine the general orientation of the policy. That was established prior to his arrival. This is significant, for it suggests that the essential characteristics of the policy were more firmly rooted in the Canadian political economy and much less dependent on King's intellectual formation than a concentration on King alone would reveal.

The elaboration of these two themes will form the background for the subsequent sections, the first exploring the considerations which, from the government's perspective, caused Canadian authorities to balk at arbitration, the second examining structural characteristics of the Canadian political coonomy which supported this bias in favour of conciliation. Throughout this paper, the focus will be on the genesis of the policy, not its practical efficacy. Of course, there is an underlying assumption that the policy had a significant effect on Canadian labour relations although any evaluation of that effect must take into account the limited aims inherent in the policy's origins, limits which this study will try to make clear. Such an evaluation, however, lies beyond the scope of this paper."

\section{The Investigator as Mediator: The Origins of Canadian Conciliation Policy}

DURING THE LAST QUARTER of the 19th century, three provinces - Ontario, Nova Scotia, and British Columbia - experimented with legislation to encourage the settlement of disputes through conciliation or arbitration. In Ontario and BC, legislation patterned on English and Australian models provided for the voluntary creation and registration of conciliation boards. Before conciliation could begin, however, the cooperation of both parties had to be secured. Consequently the legislation was little used. At a time when many employers resisted the very idea of collective bargaining, it was rare that both parties in a given dispute would consent to conciliation. Even when they did, they were much more likely to develop

\footnotetext{
${ }^{10}$ See, for example, Henry Ferns and Bernard Ostry, The Age of Mackenzie King (Toronto 1976); Craven, 'An Impartial Umpire'.

${ }^{11}$ I address this issue in part in "Standards of Industrial Justice: Ideology and the Reports of Conciliation Boards under the Industrial Disputes Investigation Act, 1907-1925," LL.M. thesis, York University, 1988, the main conclusions of which are summarized in "The Mediation of Ideology: How Conciliation Boards, Through the Mediation of Particular Disputes, Fashioned a Vision of Labour's Place within Canadian Society," Law in Context (Melbowrne), 7 (1989), 1-23. See also Bob Russell, "State Constructed Inctustrial Relations and the Social Reproduction of Production: The Case of the Canadian IDIA," Canadian Review of Sociology and Anthropology, 24 (1987), 213-31; Craven, 'An Impartial Umpire'; Webber, "Malaise"; Selekman, Postponing Strikes, 66ff.
} 
their own arrangements than bother with the cumbersome statutory machinery. ${ }^{12}$ The Nova Scotia legislation avoided this voluntaristic trap. It provided that either workers or their employer might initiate arbitration in colliery disputes, arbitration culminating in a binding award. But the Nova Scotia law had other faults. It succumbed to delaying tactics and court challenges by employers bent on undermining the regime. ${ }^{13}$ Each of these provincial experiments therefore ended in failure. Indeed, they appear to have had litule influence on federal policy. More significant was the non-statutory, purely voluntary mediation of the late $1800 \mathrm{~s}$.

Accounts of 19th-century strikes frequently refer to conciliation by local politicians, clergymen, boards of trade, members of legislatures, and other prominent individuals and organizations. There was no formal authority for this intervention. Concerned individuals simply volunteered their services when they thought necessary. This meant that these mediators - unlike the boards contemplated by the Ontario and BC statutes - could act without prior consent of the parties, although a reluctant party could torpedo the intervention by refusing to cooperate. Nevertheless this self-initiated intervention, purportedly in the public interest, foreshadowed the emergence of government-sponsored conciliation. Indeed, provincial officials appointed to administer the $1894 \mathrm{BC}$ and Ontario acts occasionally acted as voluntary mediators following one party's refusal to establish a board. ${ }^{14}$

At the federal level, the first signs of the government's growing interest in conciliation appear at the close of the century. Major strikes in key industries began

${ }^{12}$ The Trades Arbitration Act, SO 1873, c. 26; The Ontario Trade Disputes Conciliation and Arbitration Act, SO 1894, c. 42; Labour Conciliation and Arbitration Act, SBC 1894, c. 23 (see also Bureau of Labour Statistics and Industrial Disputes Conciliation and Arbitration Act, SBC 1893, c. 21, which did not require both parties' consent, but was replaced by the 1894 act). The English model was The Councils of Conciliation Act, 1867 (UK), c. 105. The New South Wales act was Trade Disputes Conciliation and Arbitration Act, SNSW 1891 -92. No. 29. Perhaps because of the ineffectiveness of these regimes they have been the subject of scant study. See, Margaret E. McCallum, "Labour and Arbitration in the Mowat Era," forthooming in Canadian Journal of Law and Society, 6 (1991); W. Steward Martin, "A Suxty of Legislation Designed to Foster Industrial Peace in the Common Law Jurisdictions of Censda," PhD thesis, University of Toronto, 1954, 120-62; Report of the Commission of Labow Enquiry, Board of Conciliation and Arbitration, BC Sessional papers, 1894-95, 589-94.

${ }^{13}$ The Mines Arbitration Act, SNS 1888, c. 3; repealed and replaced by a new version of the act with the same title, SNS 1890 , c. 7. For discussions of the origin and administration of the ach see, Margaret E. McCallum. "The Mines Arbitration Act, 1888: Compulsory Arbitration in Context," in P. Girard and J. Phillips, eds., Essays in the History of Canadian Law, vol. 3 (Toronto 1990), 303-25; Ian McKay, “'By Wisdom, Wile or War:' The Provincial Workmen's Association and the Struggle for Working-Class Independence in Nova Scotia, 1879-97," Labour/Le Travail, 18 (1986), 39ff.

${ }^{14}$ See, Report of the Commission of Labour Enquiry, 593-4; Martin, "Study," 147n. and 154. 
to assume a political prominence they had rarely possessed before. As the political interest in setuling these disputes increased, the government itself began to explore prospects for compromise. One finds, for example, the Prime Minister meeting with railway and union officials during the 1899 Grand Trunk Railway (GTR) strike, searching for settlement. ${ }^{15}$ But perhaps more important than this high-level and therefore exceptional action, the government began to use less-prominent individuals to mediate significant disputes. The emergence of this practice was most evident in the investigation, by Ontario lawyer Roger Conger Clute, of labour unrest in the metal mines of southeastem British Columbia during 1899-1900. The dispute affected many mines in the province's Kootenay region. The immediate cause was the companies' decision to reduce wages following the provincial legislature's passage of eight-hour day legislation. The way Clute used his powers is worth examining in detail, for it anticipates the kind of intervention King pursued under later legislation. ${ }^{16}$

Clute was appointed a one-man commission of inquiry, although it is clear that the government wanted him to mediate the dispute, not merely conduct a formal investigation. ${ }^{17}$ Immediately upon his appointment, he proceeded to BC and, under the guise of taking evidence, began to search for compromise. He was able to secure at least minimal cooperation because, as commissioner, he had a duty to obtain information about the causes of the strike and could compel the giving of evidence. He used this evidence as an aid to compromise, not as part of an adjudicative or fact-finding exercise. He first would interrogate one party about the issues, using questions to explore possibilities for compromise. Thus, by speaking first to one,

${ }^{15}$ Laurier to J.C. Sutherland, 2 June 1899, Laurier to A.S. Hardy, 31 May 1899, Laurier to D.J. O' Donoghue, 2 June 1899, Laurier to William Wainwright, 3 June 1899, Laurier papers, NAC, Reel C-766, 33972, 33983-4, 34019-20, 34158-9; Canada, House of Commons, Debates, 7 June 1899, 4504-5, 12 June 1899, 4858. This was the first strike of the Laurier era to achieve such prominence, a fact reflected in the character of the debate in the House. Much of the discussion concerned the appropriateness of intervention. The Opposition invoked recent English experience with government-sponsored mediation. Laurier and railways minister A.G. Blair at first resisted calls for government involvement, arguing that there was no legal authority, that they could not act without a request from the parties, and that in any case the time was not right. See Canada, House of Commons, Debates, 27 May 1899, 3776-9.

${ }^{16}$ Details of Clute's intervention are drawn principally from his report. Commission Relating to Unrest and Discontent among Miners and Mine-owners in the Province of British Columbia, Report, Canada Sessional paper No. 146, 1900; and from the Department of Justice's file, Justice Records, NAC, RG 13 A 2, vol. 1898, file 809/1899. See also the accounts in Atherton, "Department of Labour," 47-55, and Jeremy Mouat, "The Genesis of Westem Exceptionalism: British Columbia's Hard Rock Miners, 1895-1903," forthooming in Canadian Historical Review, 71 (1990).

${ }^{17} \mathrm{~S} \propto$, for example, Laurier's comments in the House, Canada, House of Commons, Debates, 22 June 1900, 8146-7. 
then to the other, Clute stimulated a kind of collective bargaining by proxy. Clute described his method:

I allowed evidence to be given at length upon this point rather with the object of taking advantage of the occasion that each might learn the views of the other than in the hope of deciding the question by weight of evidence. A lasting settlement could only be reached by a frank discussion of the difficulty and a readiness to yield something on both sides. ${ }^{18}$

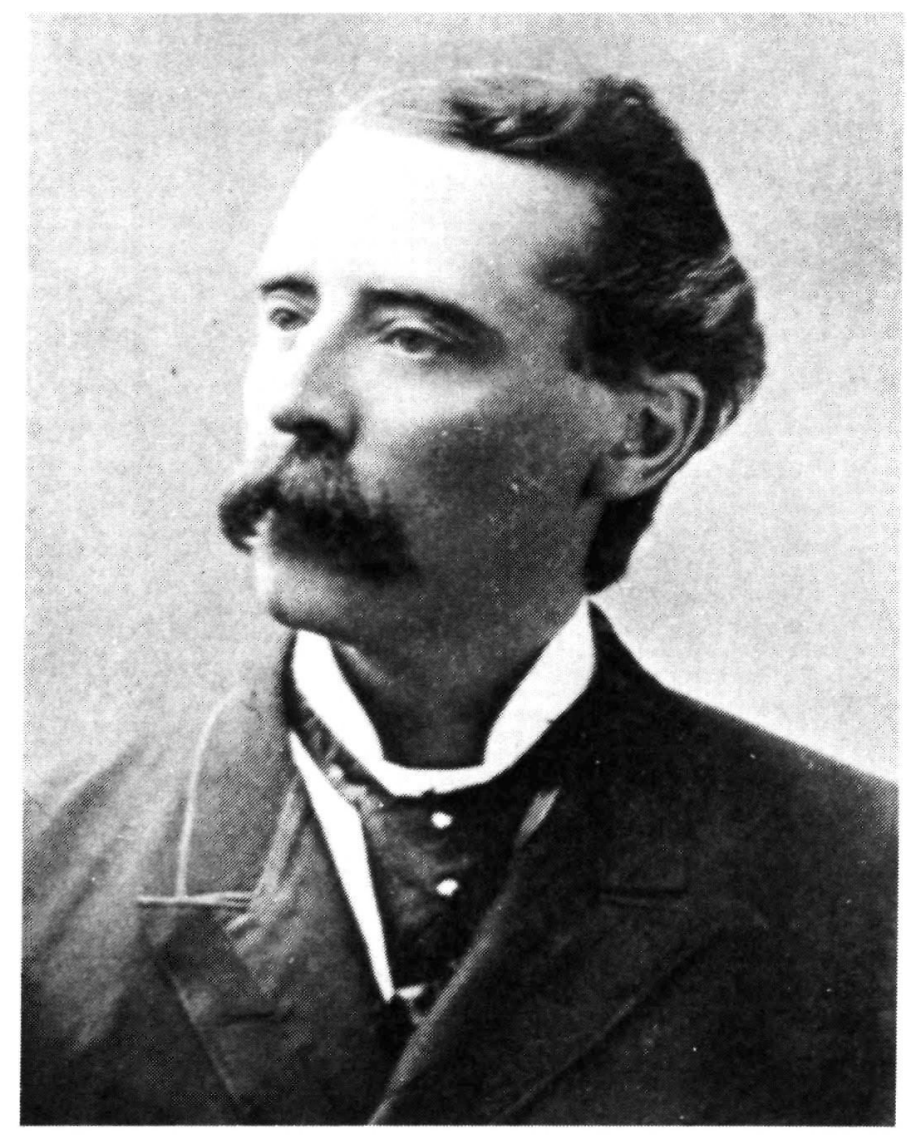

Roger Conger Clute, the Belleville lawyer who mediated the 1899-1900 dispute in the Kootenays and drafted the first federal conciliation legislation: The Conciliation Act, SC 1900, c. 24. From William Cochrane, ed., The Canadian Album. Men of Canada; or, Success by Example, in Religion, Patriotism, Business, Law, Medicine, Education and Agriculture, vol. 2 (Brantford 1893), 102.

${ }^{18}$ Commission, Report, 354. 
Clute's role was not confined to the hearings. He also worked informally, probing each party's willingness to make concessions. At one point he wrote to the prime minister, encouraging Laurier to get the owners of the mines to remove the largest single obstacle to agreement - the companies' importation of American strikebreakers. Laurier's response shows the high premium placed on securing a setulement through voluntary means, even when one party's conduct (in this case the employer's) was forbidden by law. It also emphasizes how persuasion could vary depending on whether the recipient was the employer or employees. In the Kootenays the mining companies were, to the government's knowledge, bringing in American strikebreakers - a clear violation of The Alien Labour Act of 1897. The Laurier Liberals had never much liked that act. They had adopted it reluctantly, in retaliation against an American law. Laurier found its interference with employers' freedom to hire repugnant (although at a time when the Liberals were wooing the labour vote, he no doubt appreciated labour's support for the measure). When he received Clute's request, then, Laurier did not proceed to enforce the act; rather he contacted his colleague, Senator $L J$. Forget (a major shareholder in one of the mines), to have the company end the use of Americans voluntarily. Forget raised the matter with the company's board, but the board (and Forget personally) refused to renounce the practice. Having failed at friendly persuasion, Laurier let the matter drop. Undoubtedly be wished to see the Kootenay dispute settled. He was willing to dispatch a high-profile mediator and exert personal influence to move the parties toward settlement. But he would not bring the law down on the companies, nor forcibly restrict their prerogative to deal with whom they wished (even when existing laws limited that prerogative). In the end, the companies would have to agree to any setulement. ${ }^{19}$

Clute eventually settled the dispute, although it took the workers' continued firmness, two trips by Clute to BC, and further mention of the Prime Minister's desire for settlement to get the last hold-outs, the Rossland mines, to concede the changes to the contract system and minimal degree of union recognition necessary to agreement. Clute's powers to compel evidence and his status as an agent of government contributed to his success; they made it difficult for employers to ignore his seanch for compromise. The lawyer for two of the companies, in Rossland during the investigation, said of Clute and labour MLA Ralph Smith (then President of the Trades and Labor Congress [TLC] and soon to be MP for Nanaimo, who had helped in the mediation): "I think beyond question that fact that they were in a sense Govemment representatives was a chief factor in the success which attended their efforts. 20

${ }^{19}$ Laurier to Forget, 21 January 1900, Laurier to Forget, 23 January 1900, Forget to Laurier, 25 January 1900, Clute to Laurier, 1 February 1900, Forget to Laurier, 3 February 1900. Leurier papers, NAC, Reel C-772, 41312-3, 41315, 41316-7, 41878, 41318. For the administration of The Alien Labour Act see Atherton, "Department of Labour," 238-72.

${ }^{20}$ Thomas P. Galt to Laurier, 5 May 1900, Laurier papers, NAC, Reel C-775, 45310-1. Soon after Clute's departure from Rossland, employees who had opposed the setulement began to 
Clute prepared a report describing his actions and recommending the use of similar methods in future. He advised that a projected act provide not only for conciliation boards, but also for a mediator acting alone, with power to compel evidence. This mediator should, he argued, "have power to act where he deems it advisable, on becoming aware of the dispute and without formal request by either party. ... [He] should be untrammelled by instructions or restrictions, with power however to invite assistance from the representatives of the opposing parties..." Clute's advice was accepted, and he was asked to draft the new Conciliation Act. Most of the provisions were copied from an English statute providing for the registration of voluntary boards. The uniquely Canadian contribution was section 7, permitting the government to grant a conciliator the powers of a Commission of Inquiry. This act provided the framework within which King pursued the bulk of his conciliation. ${ }^{21}$

Clute's was not the only example of government-sponsored conciliation prior to King's arrival on the scene. E.P. Bremner, a Western Federation of Miners officer hired by the Department of Justice ostensibly to inquire into violations of the Alien Labour Act, mediated strikes by BC fishermen and longshoremen in 1900 , and by fishermen and coal miners in 1901. Like Clute, Bremner used his association with the government to obtain concessions: in the first fishermen's dispute, he tried to achieve a settlement with the promise that the government would establish a commission of inquiry following the salmon season. Nor was Bremner the only Alien Labour officer. One wonders whether others also tried their hand at conciliation. At any rate, it is clear that the practice of ad-hoc conciliation by governmental officers, using powers of investigation to explore avenues of compromise and invoking a public interest in settement, was a product of the govemment's new-found commitment to industrial peace in certain key industries. It was not, as King was soon to claim, King's child. ${ }^{2}$

argue for a further strike. Clute had foreseen this and had arranged for Ralph Smith to retum to Rossland if necessary. Smith did so, and the settlement held. See Justice Reconds, NAC, RG 13 A 2, vol. 1900, file 542/1900. Violations of The Alien Labour Act continued in Rosslend. In autumn 1901 the union itself brought prosecutions against those importing American workers and appealed to the government to have the workers deported, with unsatisfying results. See, Justice Records, NAC, RG 13 A 2, vol. 1902, file 713/1901; Jeremy Mouat, "Mining in the Settler Dominions: A Comparative Study of the Industry in Three Communities from the 1800 s to the First World War," PhD thesis, University of British Columbia, 1988, 93-5.

${ }^{21}$ Commission, Report, 399; Justice Records, NAC, RG 13 A 2, vol. 1900, file 542/1900; Atherton, "Department of Labour," 53-4. The English model was the Conciliation Act, 1896 (UK), c. 30. No registrations took place under the Canadian act.

${ }^{2}$ For Bremner, Bremner to David Mills, 11 August 1900, Bremner to Laurier, 14 August 1900, Laurier to Bremner, 25 August 1900, Laurier papers, NAC, Reel C-778, 48288-96, 48282-6, 48287; Bremner to Laurier, 3 January 1901, with enclosure entitled "British Columbia Labor Report: Month ending Dec. 31 st, 1900," Laurier papers, NAC, Reel C-782. 


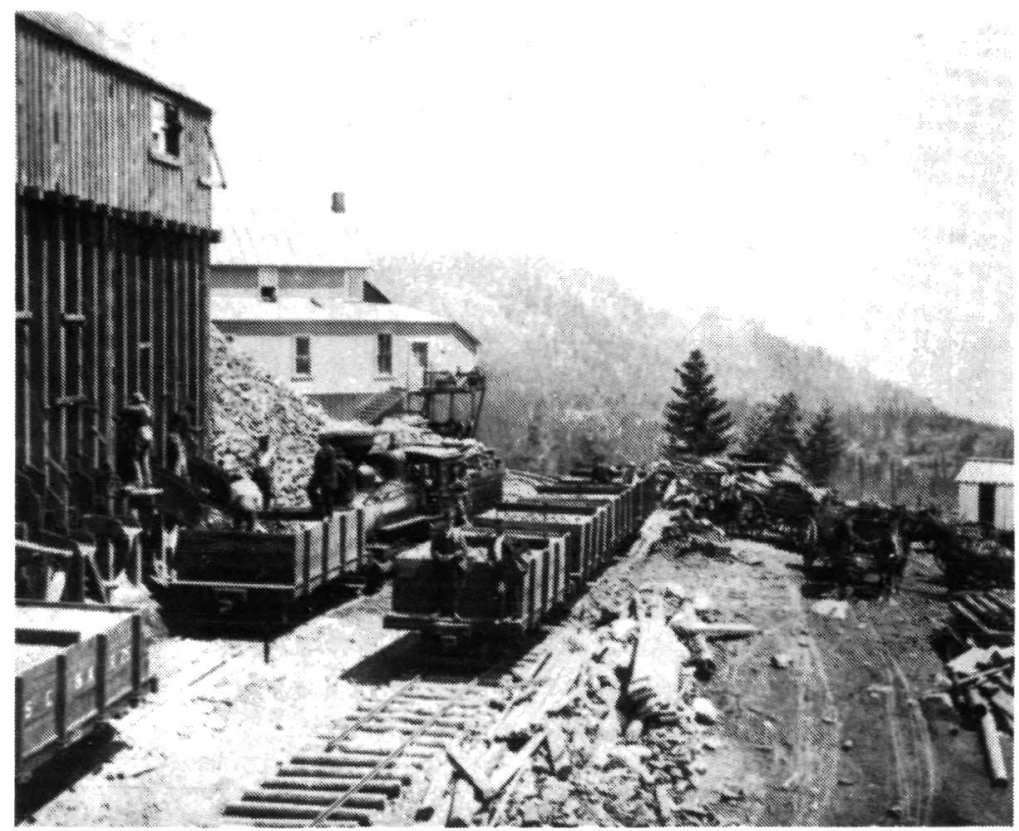

First ore train from the Le Roi mine, Rossland, BC, 6 June 1896 - one of the principal sites of disputes mediated by R.C. Clute, Ralph Smith, and W.L.M. King in 1900 and 1901. NAC/C-7859.

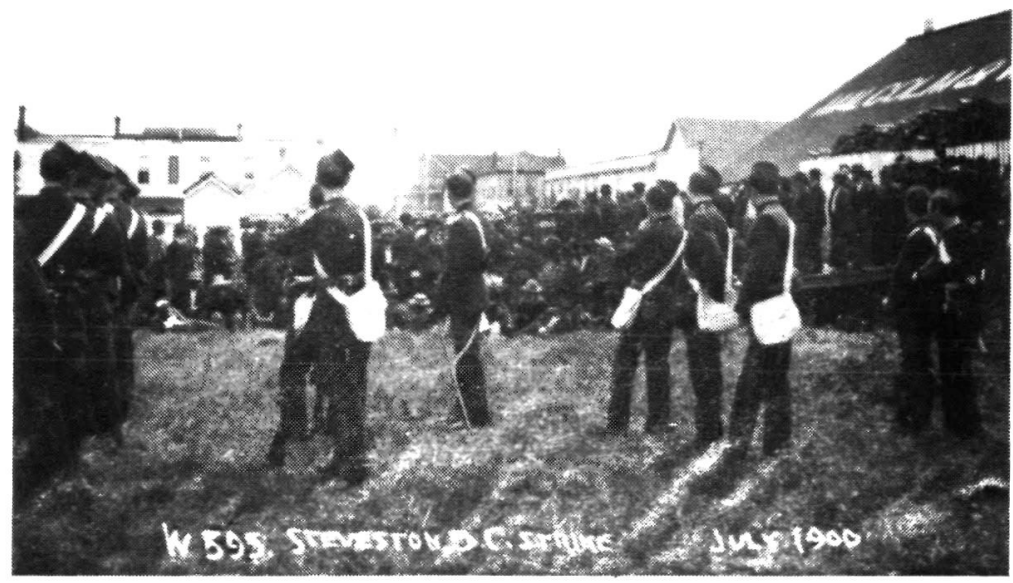

The militia face the strikers. The 6th Duke of Connaught's Own Rifles at Steveston, BC, during the strike in the Fraser River salmon fishery, July 1900. This dispute was mediated by E.P. Bremner. Photo by H.J. Woodside, NAC/PA-17203. 
But why had the Laurier government developed this compelling interest in conciliation? Until then, successive federal governments had not played such a direct role in promoting compromise (though they had appreciated others' efforts). Why the change? Here again, scholarly concentration on King has created a distorted picture. As chief publicist for the labour policy from mid-1900 on, King (in his own speeches and his coaching of ministers and government MPs) justified the regime in an idiom derived from his study of economics and Progressive social reform. He claimed that intervention in a limited set of "public utilities" was permissible (indeed necessary) because of the public inconvenience caused by shutdowns in those industries. This inconvenience resulted from the utilities' character as natural monopolies: because of the nature of the services (urban transportation, telephones, steam railways) single firms tended to dominate markets. Consumers were wholly dependent on these firms for what they now considered to be essential services. King, with the Progressives, argued that the utilities' consequent power in particular markets - a power often confirmed by the grant of preferential access to public resources (for example, the use of city streets for electric lines) - carried with it a responsibility. The community had become a "third party to industry," with a right to have its own interests protected. ${ }^{23}$

This line of argument constituted the standard justification for government involvement in labour disputes following King's arrival in Ottawa. Undoubtedly the argument had its uses, drawing as it did upon contemporary trends in economic analysis and a strong current of opinion in the United States. But there ane several indications that the primary motivation for the Canadian policy was somewhat different. This motivation was less in tune with Progressive speechmaking and more tightly tied to the central economic vision of the Laurier Liberals, a vision

52149-65; Bremner to Laurier, 3 August 1901, Laurier to Bremner, 11 August 1901, Laurier papers, NAC, Reel C-787, 57883-8, 57889-90; Eugene Forsey, Trade Unions in Canade 1812-1902 (Toronto 1982), 340-41, 366, 369-71; H.K. Ralston, "The 1900 Strike of Fraser River Sockeye Salmon Fishermen," MA thesis, University of British Columbia 1965, 105-67. There are many references to other Alien Labour officers in the Justice Records and King Pexpers, but in surviving documents no clear evidence of mediation. For King 's claims, King Diary, 16 December 1900, 27 January 1902, 10 February 1902, NAC, MG 26, J 13.

${ }^{23}$ See King's arguments for intervention in the annual reports of the Department of Labour, particularly for 1902-03, 1906-07, and 1907-08, Canada Sessional papers No. 36 for 1904, 1907-08, and 1909; also his briefing notes for the IDIA debate, King papers, NAC, MG 26. J 4, C10007-10, the basis for Minister of Labour Rodolphe Lemieux's comments in Canada, House of Commons, Debates, 14 February 1907, 3014-5; W.L.M. King, Industry and Humanity: A Study of the Principles Underlying Industrial Reconstruction (Toronto, 1973 [1918]); Craven, 'An Impartial Umpire', especially 74ff. King's influence on the terms of the debate was pervasive; comments by others have to be tested with care. On his preparation of Lemieux and labour MP Ralph Smith for a debate, see, King Diary, 9 January 1906, NAC, MG 26, J 13. 
incorporating a strongly developmental orientation, concerned more with the growth of production than with the protection of consumers.

These were, after all, the years of the Wheat Boom, when the drive to develop the Canadian West coincided with a dramatic surge in the growth of cities. The government was no passive bystander in this great national endeavour. It actively promoted expansion by subsidizing the construction of new railways, administering a developmental land policy, assisting immigration, bonusing mines and other industries, and pursuing a host of other initiatives. The government's conciliation policy was simply one component in this management of expansion. Ouawa nok only promoted the creation of an economic infrastructure, it also took steps, through its labour policy, to keep that structure operating. Indeed, the close relation of the labour initiatives to this preoccupation with development is illustrated by the subjects covered in the Labour Department's monthly journal, the Labour Gazetue: the Gazette contained information on homesteading, immigration, the extension of agriculture and industrial growth generally, as well as labour relations.

The developmental focus of the government's concem is spperent in the range of industries falling within the most influential of Canada's conciliation statutes, the IDIA. The IDIA was limited to metal and coal mines, steam railways, shipping concerns, street railways, telegraph lines, telephone compenies, and gas, electric, and water works. Not all these industries fitted easily within the Progressives' notion of "public utilities." Metal mining, for example, was not dominated by monopolies, and work stoppages in those mines had little impact on the consumer. One administrator of the act, F.A. Acland, questioned their inclusion for just that reason. Yet the list makes sense when the act is seen as part of the government's developmental strategy. All the industries listed were tightly linked to the developmem of the West or the orderly expansion of cities. An important component in the government's plans for British Columbia, for example, was the exploitation of mineral resources. In 1897, Parliament had approved generous subsidies to the CPR for the construction of the Crow's Nest Pass extension, specifically to create an all-Canadian transportation route to the metal mines of BC's Kootenay region. Clute's investigation, concerned with those very mines, shows the close relationship between developmental aims and labour policy. On a number of occasions, Clute mentioned the fear that labour unrest might discourage investment in the region. Similar concerns were expressed in the House of Commons.

Indeed, each step in the evolution of Canada's conciliation legislation was prompted by a major dispute in an infrastructural industry. The 1900 act was adopted in the middle of the first strike wave of the Laurier era, involving unprecedented organizing drives in metal and coal mining and steam and street railways. The act itself was a direct result of the Kootenay conflict of 1899-1900, and followed closely upon Laurier's involvement in the GTR strike of 1899. A 1901 strike on the CPR led to the 1902 arbitration bill and the 1903 investigation act. The drafting of the IDIA was triggered by a long coal strike in southwestern 
Alberta, which raised concerns that there would be a shortage of fuel for prairie settlers."

This commitment to development meant that Ottawa's general objectives complemented those of employers: each defined success in terms of the expansion of privately-owned capital. The government did not, however, share the tactical perspective of each employer. The government sought the expansion of the economy as a whole. In specific disputes, this interest might well diverge from that of the employer, leading the government to push for concessions beyond those the employer would have made on its own. Thus in the Kootenays, the government encouraged mine-owners to settle because continued strife imperilled broader developmental goals by closing smelters, inflicting losses on the railways, and discouraging investment in new mines.

There was another way in which economic development shaped Ottawa's concern with labour conflict, one based on the need to justify the subsidization of industry to citizens who were not themselves owners of capital. Many Canadians were willing to support the use of bonuses, land grants, franchises, and mineral grants if something like the intended benefits were realized. But if the conduct of developmental enterprises undermined those benefits (by interrupting service or by denying workers a fair share of prosperity) grievances against firms could be transformed into demands for govemmental action, especially the ending of further assistance. Although the giving of subsidies did not, in the minds of most observers, make the state directly responsible for the sins of the companies, it certainly resuricted the state's ability to dismiss the corporations' conduct as purely a private

\footnotetext{
"The Incustrial Disputes Investigation Act, SC 1907, c. 20, s. 2(c); F.A. Acland, "Canadian Legislation Conceming Industrial Disputes," Canadian Law Times, 36 (1916), 217; Commission, Report, passim; Canada, House of Commons, Debates, 22 June 1900, 8146-7, 6 July 1900, 9374. See also King's comments during a dispute in BC's metal mines in 1901, King Diary, 19 November 1901, NAC, MG 26, J 13. In the correspondence leading to the creation of the 1903 WFM/UBRE strike commission (discussed below). Minister of Labour Sir William Mulock emphasized the detrimental effect of labour unrest on mining development, Mulock to Laurier, 4 April 1903, Laurier papers, NAC, Reel C-799. 71788-9. See also, Telegram, Duncan Ross to Laurier, 17 February 1903, Laurier papers, NAC, Reel C-798, 70304. Although the 1899-1903 strike wave involved many disputes in manufacturing and construction, it was the railway and mining disputes that attracted the government's attention. See Douglas Cruikshank and Gregory S. Kealey, "Strikes in Canada, 1891-1950," LabouriLe Travail, 20 (1987), 100ff. The burden of the government's concern is also apparent in its treament of safety issues arising when struck railways tried to maintain operations. Government representatives decried the danger to life and limb, but were unwilling to interrupe service. See Mulock's comments, Canada, House of Commons, Debates, 29 April 1902, 3725-6.
} 
maner. The political credibility of subsidized development depended in part on the perceived good conduct of the recipients. ${ }^{25}$

The government responded by adopting a stance which by no means renounced stente support for industry, but which emphasized the government's independence from the specific policies of management. Ottawa presented itself as a neutral in labour conflict, ensuring that both parties fulfilled their obligations to the community. Private initiative remained fundamental to economic growth, but the public had to receive its due: the continued operation of developmental industries. Labour minister Sir William Mulock made this argument when introducing the Railway Arbitration Bill of 1902:

Railways are the creatures of parliement, they are created in the public interear, and for that reason they are given rights peramount to those of the individual. They are creatiod to serve the public, in the first place, and it is the duty of the people's representmives to see that the object of perliement in grenting cherters is not defested, either by the compeny or by their employees.

The government would intervene, but as a neutral third party seeking to secure the continuation of publicly-subsidized services. King's arguments served as a convenient justification for this approach. They too spoke of even-handed intervention in industries affected with a public interest. King's rationalizations and governmental strategy were compatible, but the primary impetus for Ottawa's policy lay in a conception of the public interest pre-dating (in the Canadian context) King's consumer-conscious, nondevelopmental thetoric of Progressivism. ${ }^{25}$

Thus, when King arrived in Octawa in July 1900, the government had already initiated, as an adjunct to its developmental policy, the form of conciliation that King was to exploit so successfully. King quickly became the government's chief

${ }^{2}$ Demands for government intervention were frequently linked to the public benefius beasowed on struck employers. See the positions of the Trades and Labor Congreas, tying intervention to the receipt of public franchises or contracts, Forsey. Trade Unions, 442, 486. See also comments in the House on the 1899 GTR strike, the 1903 lock-out of Vencouver Islend miners and the IDIA debates, Cenada, House of Commons, Debates, 7 June 1899. passin; 3 April 1903, 947; 6 February 1907, 2606-8. Alsa, Report upon the Sweating System in Canada, Canada Sessional paper, No. 61, 1896, 18; Labowr Gozerte, 3 (1902), 273; Labour Gazette, 12 (1912), 762; Labour Gazette, 13 (1912), 359.

${ }^{2}$ Ceneda, House of Commons, Debates, 29 April 1902, 3725-6. On a number of occasions the government considered extending the IDIA to other industries, but never did so (except during wartime, obviously in response to a temporary redefinition of the national purpose). It seems that only the building trades were seriously considered for inclusion in peacetime. See, Labour Gacette, 9 (1909), 1114; Labow Gazette, 10 (1909), 579-80; Labour Gazette. 11 (1911), 1260. This sector was, in its developmental implications, similar to the included industries, but it lacked the state involvement inherent in the grant of franchises or the allocation of natural resources. 
conciliator (indeed, virtually its sole conciliator). ${ }^{27}$ During the next seven years, he intervened in some $\mathbf{4 0}$ disputes, achieving a high rate of setulement. The nature of his intervention has been described elsewhere. ${ }^{2}$ His approach was very similar to Clute's. Like Clute, King often claimed he was intervening simply to discover the facts. He would then interview each party, searching for compromise. King did this without the powers of a commissioner (although he considered asking for them in a 1901 Rossland strike, and Royal Commissions into labour disputes were established in 1903 and 1907). ${ }^{2}$ Probably the powers of a commissioner were unnecessary in many disputes, and the government was reluctant to intervene 100 dramatically in the remainder. appointing a commissioner - especially when the commissioner was deputy minister of labour - inevitably raised expectations that the government would act docisively to secure a settlement.

From the beginning, the fledgling Department of Labour justified its intervention in terms analogous to arbitration, but with public opinion rather than state power as the enforcement mechanism. In a speech apparently delivered in January 1901, King's close friend and assistant at the labour department, Henry A. Harper, described the "arbitrement of public opinion" as follows:

The prestige of the Government behind the Conciliator enables him to deal fully with each perty and to throw the full light of day upon the actual condition of affairs. This done the full strength of the system of voluntary conciliation comes into play. Public opinion will

${ }^{27}$ This was not the result of King's talent for compromise abone. In 1900-01 King worked hard to freeze Bremner out of the conciliation game, a task which succeeded when Bremner overplayed his hand in the Dunsmuir coal dispute of 1900-01. After the government had rejoctod Bremner's request for the powers of a Commissioner in that dispute. Bremner made the mistake of writing Laurier, threstening to denounce the government publicly. See, King Diary, 13, 14, and 22 March 1901, 10 and 22 August 1901, 4 September 1901, 23 November 1901, 18 February 1902, NAC, MG 26, J 13; Bremner to Laurier, 3 August 1901, Laurier to Bremner, 11 August 1901, Leurier papers, NAC, Reel C-787, 57883-90.

The extent to which King benefited from advice from other conciliators is unclear. Immoctiately upon his arrival in Ottawa, his diaries note that he was reading extensively on conciliation, King Disry, 27, 28, 30 and 31 July 1900, NAC, MG 26 J 13. The entry for 4 Jemery 1901 records a meeting with Clute.

"Craven 'An Impartial Umpire', 231ff; William M. Baker, 'The Miners and the Mediator: The 1906 Lethbridge Strike and Mackenzie King," Labour/Le Travaillewr, 11 (1983), 89-117.

King Dirry, 29 and 31 October 1901, 18 November 1901, NAC, MG 26, J 13; Report of the Royal Commission on Industrial Disputes in the Province of British Columbia, Cenuda Seasional paper No. 36a, 1903; Report of the Royal Commission on a Dispute respecting terms of Employment between Bell Telephone Company of Canada and Operators at Toronto (Ouawa 1907); Joen Sangster, "The 1907 Bell Telephone Strike: Organizing Women Workers," Labour/Le Travailleur, 3 (1978), 109-30. Bremner requested (unsuccessfully) the powers of commissioner, Bremner to Leurier, 3 Janurry 1901, Lenrier papers, NAC, Reel C-782, 52149-50, 52165. 
force a settlement which a least aproximates so, justice and faimess. The mean perty, whather it be the employer or the labour argenization, must inevitubly give way wo the extert of its mesrmess.

Yet already it was the threat rather than the reality of publicity that was used in practice, and then simply to induce compromise. In the same speoch, Harper notod that the mere possibility of public investigation would cause the employer "to give greater consideration to a proposal for the creation of a permanent conciliation boerd" (in the usage of the day, would encourage direct bergaining between employer and employees). King revealed the full significance of this for the practice of conciliation when, in 1906, he instructed his Minister on how to secure concessions:

Your strong weapon in any negotiations is to point out that as Minister, under the Act, you are obliged to ecquaint parliament and the public with the fects in comection with the simation, and that you hope it will not be necessery for you to draw attention to what appeers to be en unfair position of one side or the other.

"Draft speech entitled "Canade's Autitude Towards Lebour," Harper pepen, NAC, MO 30, A 28, vol. 2; King Diary, 18 January 1901, NAC, MG 26, J 13; King wo Lemieur, 20 September 1906, King papers, NAC, MG 26, J 1, vol. 5, 5065. King's rejoction of the commissioner's powers in the 1901 Rosslend dispute also shows their concilistory purpose. He rejected them because, in his view, the strike was lost (Inthough be soems to have been influenced in this opinion by his disepproval of the union), King Dirry, 18 and 19 November 1901, 10 Jermery 1902, NAC, MG 26 J 13; King to H.A. Harper, 18 November 1901, King to Mulock, 18 November 1901, King papers, NAC. MG 26, J 1, vol. 3, 2426-8, 2553-8; Mourt, "Settler Dominions," 89-99. Correspondence between King and Mulock prior to his intervention suggests it was the threat, rather then the application, of inveetigatory powers that was importent. See, Mulock to King, 5 November 1901, King pepens, NAC, MG 26, J 1. vol. 3; King Diery, 29 October 1901, NAC, MG 26 J 13. See alvo King's scoount of bow he obuined concessions from the Nova Scotia Steel Compeny in 1901 (King to Mulock 28 June 1901, King papers, NAC, MG 26, J 1, vol. 3, 2542-2543), "The company strited that they were not anxious to have a full investigation by arbitration [under the 1890 Nova Scotia sct], if that could be avoided, inasmuch as such a course would necessitate certsin disclonures which, from their point of view, might be prejudicial to the best interests of the compeny. and they, therefore, were also prepured to have the matter setuled by conciliation if possible."

Bremner, a former official of the WFM, does not seem to have shared this purely rectical view of investigation. He took it at face value, $3 \mathrm{a}$ means of getting accurate information into the hands of the union. This may have contributed to his falling out with the government, which wes caused in part by the refusal to grant him investigatory powers. See, Bremner to Laurier, 14 August 1900, Laurier papers, NAC, Reel C-778, 48282-6; Bremner to Laurier. 3 Jenuary 1901, Leurier papers, NAC, Reel C-782, 52149-65; Bremner to Leurier, 3 August 1901, Laurier papers, NAC, Reel C-787, 57883-8. 


\section{LABOUR/LE TRAVAIL}

But despite his successes during these years, King's conciliation suffered from some of the defects of purely voluntary intervention. King could initiate contact with the parties, pertaps beginning conciliation in circumstances where neither perty would seek outside assistance, yet both would cooperate. But King could do little in those disputes where the employer resolutely refused any intervention, resisting even the modicum of recognition implied in mediation. Indeed, the government, rather than risk an embarrassing rebuff, adopted the practice of intervening only after both parties had given their consent. This meant that in some of the fiencest disputes the govermment was powerless to intervene. The catalyst for the next legislative innovation was one such dispute - the 1901 strike of maintenance-of-way employees on the CPR. ${ }^{31}$

The central issue in that strike was union recognition (although wages were also in dispute). The Department approached CPR President Sir Thomas Shaughnessy to secure his agreement to conciliation, but Shaughnessy declined. The strike dragged on, and the failure to maintain the line began to take its toll. The Labow Gazette reported matter-of-factly: "In the latter part of the month [July] a few wrecks and run-offs occurred and this number was supplemented by others in the month of August." Delays on the line impeded the transportation of grain, but because of Shaughnessy's refusal no governmental intervention occurred. The workers eventually won their battle, with the final setulement arranged through the mediation of the railway running-trades unions. ${ }^{32}$

This dispute generated the first serious discussion of compulsory arbitration in Outawa. On 15 August, King gave TLC Secretary Paddy Draper some "hints" or "suggestions" of what proposals might be appropriate in the TLC Executive's report for that year. These included: "Compulsory arbitration might be tried in all cases of dispute arising where Govt. contract work being done, or when Govt. bonuses granted, \& both parties to a dispute too rigid to furnish statistical accts. to $D$ [epartment] of $L$ [abour]..." In the diary entry noting Shaughnessy's un willingness to conciliate, King also reported a conversation King had had with Mulock following the latter's return from a trip to Australia and New Zealand. "I think," King wrote, "he [Mulock] has become much more interested in labour problems, \& that he has seen more fully the significance of them. He did not favour the Compulsory Arbitrat'n of New Zealand \& thought a reaction had set in against the

${ }^{31}$ For other disputes in which the inability to obtain consent caused concern, see, Kingston Locomotive Works strike (Canada, House of Commons, Debates, 17 May 1901, 5434ff); Crneda Atlantic Railway strike (Report of the Department of Labour for the year ending June 30, 1903, Canada Sessional paper No. 36, 1904, 39-40); Buckingham strike (Canada. House of Commons, Debates, 10 December 1906, 797, 14 February 1907, 3003, and Report of the Department of Labour for the ... fiscal year 1906-07, Canada Sessional paper No. 36, 1907-08, 32).

${ }^{3}$ King Dirty, 22 August 1901, NAC, MG 26 J 13; Labour Gazente, 2 (1901), 173ff. See Mulock's comments on the "wheat blockade" during his introduction of the 1902 arbitration bill in Canada, House of Commons, Debates, 29 April 1902, 3726. 
Labour men in Australia" One month later, BC labour MP and TLC President Ralph Smith, Mulock, and King again discussed the possibility of enacting an arbitration regime, though King believed that the proposal "will likely resolve itself into an amendment giving Govt. power to take initiative into enquiry re railway disputes, but not more." ${ }^{33}$

These discussions did not immediately bear fruit. As the quotations suggest, the principals were not at all certain that arbitration was the best approach. But throughout the winter of 1901-02 arbitration remained on the agenda. The event which seems to have moved the government to action occurred in February. Shaughnessy, still smarting from his defeat in the 1901 strike, wrote Laurier to suggest the creation of an industrial tribunal. He wrote:

These strikes on a railway, reculting in the stoppage or the serious obetruction of traffic, are a source of such very great public inconvenience and loss that it scems to me they warrant the consideration of Parliament. I notice that in one of the Continental Countries a law has been passed, prohibiting railway strikes, upon the ground that meen, who are engagod in cerving the public, must find other means of settling their disputes then by quitting work and impoding commence.

Shaughnessy apparently believed that a tribunal's decision would produce a more advantageous result than industrial conflict. He discussed the question with $\mathrm{King}$ and GTR General Manager Charles Melville Hays, but Hays was cool to the idea.

At this point, the archival record peters out. What is clear is that on 29 April 1902. Mulock rose in the House to present a bill providing for binding arbitration on steam and street railways. Although Mulock spoke in favour of the bill, he suggested that it was not intended for immediate passage but only for circulation among the interested parties. He expressed his intention to consult widely, taking definitive action during the next session of Parliament. He suggested that railway employees "almost to a man will endorse the principle of compulsory arbitration," and that the main obstacle to passage would probably be opposition from the railway companies. In such circumstances, he said, the government might have to impose arbitration "in the interest of the public." The depth of his commitment is uncertain, however. We do not know who was primarily responsible for the bill. Judging from King's diaries, both Mulock and King were doubtful about the merits of arbitration. Throughout this period, King vacillated between advocating arbitration in the most essential of services (especially railways) and supporting compulsory investigation alone. The most consistent arguments for arbitration came from Ralph Smith, who as a labour MP friendly to the Liberals carried some persuasive

${ }^{33}$ King Diary, 15 and 22 August 1901, 30 September 1901, NAC, MG 26 J 13; King to H.A. Harper, 24 August 1901, King papers, NAC, MG 26 J 1, vol. 3, 2382.

${ }^{34}$ Shaughnessy to Laurier, 4 February 1902, Laurier papers, NAC, MG 26 G, vol. 222. 62541-2; Atherton. "Department of Labour," 175-7; Craven, 'An Impartial Umpire', 274-6. 
weight, although he was not directly involved in the framing of policy. It seems that on balance the bill was what it purported to be - $a$ trial balloon, designed to test support for arbitration. Mulock's interest in arbitration was recent. King's own ideas were still in formation. Laying a concrete proposal before the representatives of labour and capital might serve to focus the debate. ${ }^{35}$

The 1902 bill was never adopted. I will postpone a complete discussion of the reasons until Parts 3 and 4 of this paper, for the fate of the 1902 bill is best explained as one episode in the government's persistent refusal to move beyond compromise to the imposition of substantive terms. But one factor can be noted here. The bill did crystallize opinion, but not in the direction Mulock expected. Although there were dissenters within the railway unions, the leaders of those unions came out against the bill (no doubt sharing Shaughnessy's understanding of the probable outcome of adjudication), and in September 1902, the takeover of the TLC by unions affiliated with the American Federation of Labor led the TLC to renounce arbitration. Faced with outright opposition from influential representatives of employers and employees alike, the government abandoned the bill. ${ }^{36}$

Mulock and King did, however, turn their minds to alternative regimes. The first days of January 1903 found King hard at work on a substitute bill, again limited to railways. He had turned away from adjudication and toward a patently investigative framework. The appeal to public opinion which Harper had said existed under the 1900 act would be formalized in the 1903 legislation. As King noted in his diary, the aim of the new regime "should be to afford a means of the public getting an intelligent view of the facts of the situation and of bringing an enlighted [sic] public opinion to bear." Either party to a dispute could apply for a Committee of Conciliation made up of one nominee of the employees, one of the employer, with a third chosen by the first two (or, failing agreement, by the Minister). If this Committee were unable to settle the matter, the Minister could refer the dispute to an ad-hoc Board of Arbitration, having the same structure as the Committee and,

${ }^{35}$ Canada, House of Commons, Debates, 29 April 1902, 3725-33; King Diary, 11, 12 and 14 January 1901, 15 and 22 August 1901, 30 September 1901, 2 and 4 January 1903, 15 May 1903, NAC, MG 26, J 13; King to Harper, 24 August 1901, King to Charles Francis Adams, 13 Janury 1903, King papers, NAC, MG 26, J 1, vol. 3, 2382, 2866; Draft speech. King papers, NAC, MG $26 \mathrm{~J} 4$, vol. 31, file 181; Report of the Department of Labour for the year ending June 30, 1903, Canada Sessional paper No. 36, 1904, 58ff. On Smith and arbitration, see Mouat, "Genesis." Craven suggests that Mulock was responsible for the bill. 'An Imparial Umpire', 275. Atherton chooses King, "Department of Labour," 177. The evidence is inconclusive.

${ }^{36 .}$ Railway Labour Disputes Bill, 1903. Expressions of Opinion," Department of Labour Records, NAC, RG 27, vol. 71, file 322.1(3); King to Mulock, 31 July 1902, King papers, NAC, MG 26, J 1, vol. 3, 2815; Labour Gazette, 4 (1903), 137; Report of the Department of Labour for the year ending June 30, 1903, Cansda Sessional paper No. 36, 1904, 59; Craven. 'An Impartial Umpire', 276; Robert H. Babcock, Gompers in Canada: A Study in American Continentalism Before the First World War (Toronto 1974), 85-97. 
if the parties agreed, the same members. The Board would have power to summon witnesses, documents, etc., and would make a non-binding report proposing terms of settlement.

The form of this act drew extensively on foreign models. King's papers recond that while working on the act, he examined an Illinois arbitration statute and a draft bill prepared by Charles Francis Adams for the US Anthracite Coal Strike Commission. Undoubtedly, he was familiar with the type of investigation used since the 1880 s to settle labour disputes in New York and Massachusetts. He would also have seen the report of the US Industrial Commission of 1902, which reviewed American experience with investigation and proposed further refinements to that system. King's 1903 act echoed many features of those regimes. The American legislation had traditionally emphasized the role of publicity in the settlement of disputes. Experience with those statutes had also revealed the need for close attention to the means of initiating intervention: if investigation depended on the prior consent of both parties, it would be hamstrung. King's act carefully avoided this problem by permitting either party to begin proceedings. Finally, Americans had learned (as Clute had done) the value of investigatory powers in conciliation. The US Industrial Commission observed: "the power of a State board to compel disputants to come before it and give evidence enables the board often to bring the parties into conference and thus to effect amicable setulements." Under King's new act, the Board of Arbitration would possess those powers. Many of these lessons had also been identified in an earlier report that King must have read: the 1891 report of the New South Wales Royal Commission on Strikes. That document, growing out of the 1890 maritime strike in Australia and New Zealand, had rocommended that boards investigate disputes, relying on public opinion rather than state compulsion to enforce their awards. It had also argued that either party be able to initiate intervention. The significance of this last recommendation was confirmed with some irony by experience under the statutes inspired by the NSW report: statutes in NSW, BC and Ontario all departed from the report by requiring that both parties consent. As a result, all were ineffective.

JKing Dirry, 3 January 1903, NAC, MG 26, J 13; The Railway Labour Disputes Act, S.C. 1903, c. 55.

${ }^{30}$ C.E. Norton to King, 26 January 1903, King papers, NAC, MG 26, J 1, vol. 3, 3075; King Diary, 2 January 1903, NAC, MG 26, J 13; Anthracite Coal Strike Commission, Report to the President on the Anthracite Coal Strike of May-October 1902 (Washington 1903). Appendix I; Final Report of the Industrial Commission (Washington 1902), quotation from 854; Report of the Royal Commission on Strikes (Sydney 1891); experience under BC and Ontario acts discussed above, at 5-6. On the early American experience with investigation, soc, Carroll D. Wright, Industrial Conciliation and Arbitration (Boston 1881).

In 1902 and 1903, the labour member for Winnipeg. A.W. Puttee, had proposed amendments to The Conciliation Act along similar lines, permitting either party to initiate intervention, giving the "arbitratos" power to compel evidence, and contemplating the 
Two features of King's act, however, were not copied from other juristictions. Both reflected his opinion that investigation was to be, above all, an aid to conciliation. First, the initial mediating body - the Committee - did not have investigatory powers; those powers were reserved to the Board. This two-stage process was unwieldy in practice, but in conception it probably reflected King's preference for using investigation simply to induce compromise: the mere possibility of investigation would make conciliation more effective. Second, the act did not follow the American or NSW precedents by creating permanent boards composed of public officials. Under King's sact, each board would be appointed for each dispute, with board members chosen by the immediate parties. This sacrificed impartiality to conciliatory impact, emphasizing the boards' role as forums for compromise. Indeed, if practice under the IDIA is any indication of King's intentions, the boards would at times act as bargaining committces, the parties' nominees negotiating within the board, often following their principals' express instructions. King's objective was accurately summarized in his diary entry: "I wd. rather make the whole an addition to Conciliation, thereby strengthening the power of the former \& minimizing the need of arbitration. Machinery is nothing, personality everthing." ${ }^{39}$

After consultation with the railway unions, the bill was passed through the House. It became law during a period of relative peace on the railways. It was

enforcement of the award by public opinion (not by the state). There were three significant differences between Puttee's initiative and the 1903 act: 1) Puttee's bills applied across the entire economy; 2) the arbitrator was bound to take evidence and render an award (placing much less emphasis on conciliation); 3) they forbade the arbitrator from recommending that employees renounce union membership. See, 1902 Bill No. 32, Records of Parliament, NAC, RG 14, D 11, vol. 1847. File: Public Bills and Orders 1902; Canada, House of Commons, Debates, 10 March 1902, 881-2, 8 April 1903, 1193.

${ }^{39}$ King Diary, 2 January 1903, NAC, MG 26, J 13. A two-step process was also used in The Industrial Conciliation and Arbitration Act, SNZ 1894, No. 14, and the Trade Disputes Conciliation and Arbitration Act, SNSW 1891-2, No. 29. These acts provided for permanent boards, departing from the NSW Royal Commission on Strikes which had recommended a one-atage process using ad-hoc boards. That Commission revealed the conciliatory advantage of having parties' representatives on boards (Report, 29): "[The representatives] will inevitably have the bias of their class, and will foel some responsibility towards their associates for upholding their class interests, and therefore at the Boand will act in the mixed capecity of advocates and judges. On the other hand, it must be bome in mind that in the absence of compulsion to enforce the award it is all-important that it should be voluntarily acquiesced in, and that therefore, both sides should be contented with the constitution of the tribunal." Accounts of many IDIA investigations show that bargaining occurred within the board. See Webber, "Standards of Industrial Justice," 82-4. When one chairman wrote King to complain of this, King's reply echoed the NSW commission's argument, Charles W. Gordon to King, 25 June 1909, King to Gordon, 2 July 1909, King papers, NAC, MG 26, J 1, vol. 11, 10508-13. 
invoked only once prior to the adoption of the IDIA - in a 1904 GTR telegraphers dispute. Throughout those proceedings the government emphasized conciliation, trying if at all possible to secure a compromise. In the end the Board of Arbitrators did make a formal award, which the employer rejected. Negotiations resumed, resulting ultimately in a settlement at a wage-rate below that suggested by the Board. The employer's failure to implement the award caused considerable consternation among the telegraphers. Workers did not always share the government's commitment to accommodation, especially when they believed that an impartial tribunal had upheld the justice of their claims. ${ }^{*}$

It may be useful to mention one further instance of government intervention in 1903, one which is remarkable for its contrast to the main theme of this account. I have emphasized throughout that the government used investigation as an aid to conciliation. On one occasion, however, Ottawa used investigation to condemn a union outright. This was the 1903 strike of Vancouver Island coal miners and of miscellaneous workers (chiefly clerks and freight handlers) on the CPR's western lines. This dispute had, for the government, particularly unpleasent overtones, for it seemed to involve an alliance between two radical unions, the Weatern Foderation of Miners and the United Brotherhood of Railway Employees. The WFM had already caused the government some trouble. It had led the Kootenay miners in the 1899-1900 dispute mediated by Clute. The Rossland local of the WFM had struck again in the fall of 1901. King had gone to BC to mediate that dispute, but on arrival concluded that the employees had struck without justification and declined to do more. Early in 1903, King had again travelled to southeastern BC, this time to settle a WFM dispute in the coal mines. The combined dispute on the CPR and Vancouver Island must therefore have seemed yet another episode in an exasperating pattem of conflict. Not only that, but the unions involved preached class struggle and had forged a working alliance across industrial boundaries.

The government reacted forcefully. In response to a call from Ralph Smith (MP for a Vancouver Island mining constituency), a Royal Commission was appointed to investigate the dispute. But the government did not share Smith's deference to the workers' choice of union. Mulock wrote to Laurier.

Pechups it would assist to disillusion [the workers] if an intelligent commission, one in which the working people had confidence, were to point out the injuries that have come to them because of the interference of the American Unions.

${ }^{40}$ King Diary, 17 January 1903, NAC. MG 26, J 13; King to Mulock, 20 June 1905, King papers, NAC, MG 26, J 1, vol. 4, 4086; Report of the Department of Labour for the year ending June 30, 1904, Canada Sessional paper No. 36, 72-3; Report of the Department of Labour for the year anded June 30, 1905, Canada Sessional paper No. 36, 63ff. 
The Commission, with King acting as secretary, followed Mulock's advice, even though to do so it took some liberties with the evidence. In particular, it damned the WFM as "really not a trade union at all, but a secret political organization."

In this instance, the government used investigation to marshall public support for the employers' refusal to recognize the unions - indeed to attack the unions' very existence. This heavy-handed intervention was exceptional, however. I have come across very few cases of a government-appointed board directly attacking a union. Even in later disputes involving the WFM, conciliators tried to settle the issues through compromise (although the govemment remained decidedly cool towards unions which, like the WFM, were frank opponents of the capitalist order). The government was willing to pursue compromise - indeed preferred accommodation to confrontation - as long as negotiations took place within a framework which recognized, at least implicitly, the legitimacy of privately-owned capital. ${ }^{42}$

The years following 1903 were a time of welcome inactivity on the legislative front. The next innovation came in 1907, with the adoption of the IDIA. Once again, the immediate cause was a strike in an infrastructural industry: the coal mines of southwestern Alberta. The strike curtailed coal production throughout much of 1906. The onset of winter prompted fears of a "coal famine" on the treeless prairies, where settlers were dependent on coal for heat and cooking fuel. Once again, the parties initially declined the Department's offer of intervention, but eventually relented. King settled the dispute using the familiar combination of interviews, threats, and government prestige. The strike prompted King to legislative reflection, however, and on his return to Ottawa he drafted the culmination of the Canadian conciliation statutes, the IDIA. ${ }^{43}$

${ }^{41}$ Cande, House of Commons, Debates, 3 April 1903, 946ff; Mulock to Lauriex, 4 April 1903, Laurier papers, NAC, Reel C.799, 71788; Report ... on Industrial Disputes in the Province of British Columbia; Craven. 'An Impartial Umpire', 246-52; J. Hugh Tuck. 'The United Brotherhood of Railway Employees in Westem Canada, 1898-1905," LabourlLe Travaillewr, 11 (1983), 63-88; Allan Donald Orr, "The Western Federation of Miners and the Royal Commission on Industrial Disputes in 1903 with Special Reference to the Vancouver Island Coal Miners' Strike," MA thesis, University of British Columbia, 1968.

Mulock's comments, covering all Americen unions (inchuding AFL affiliates), cast the net wider than King thought justified. King, the BCCommission report and the govemment's policy generally did not express the view (common among employers and their defenders in the Senate) that all American unions were illegitimate. Allegations of illegitimacy were tied to unions' militancy or politics, not merely their nationality. See, Craven, 'An Impartial Umpire', 132-6, 250-2.

${ }^{42} \mathrm{See}$, Webber, "Standards of Industrial Justice," 193-202.

43. Confidential Memorandum re Lethbridge Strike," King papers, NAC, MG 26, J 4, vol. 13, file 80; King Diary, 4, 9, and 16 December 1906, 1, 2 and 3 January 1907, NAC, MG 26, J 13; Craven, 'An Impartial Umpire', 264-9; Baker, "The Miners and the Mediator;" Allen Seager, "A Proletariat in Wild Rose Country: The Alberta Coal Miners, 1905-1945," PhD thesis, York University, 1981, 208-17. 
In his preparation of the new act, King again reviewed the legislation of other juriadictions, particularly New South Wales and New Zealand, but it is clear that the IDIA was, as King claimed, the product of his experience as a mediator. Many of its provisions echoed the practice of the previous seven years. The IDIA retained the 1903 act's emphasis on public investigation, although it collapsed that act's two stages into one. Either party could initiate proceedings, resulting in an ad-hoc boerd with one member nominated by the employer, one by the workers, with the thind chosen by the first two. These boards had power to compel evidence. But atthough the IDIA (like the 1903 act) seemed to contemplate a full investigation followed by a public award, its authors still saw the measure as an aid to compromise. The act itself stated that the boards' first duty was to obtain a settlement. The briefing notes to the minister similarly stressed conciliation. When read in light of the practice prior to 1907 , they strongly suggest that investigation was to be used for getting the parties talking in the first place, and for prying concessions bose in the second - not for exposing all facts to public view:

The main duty of the Board shall be to try and effect a settlement of the difficulty. It is expected that in a large number of cases after the Board has ascertained certain facts and hes represented these facts with their bearing to the contending perties, an adjustment of the difficulty will be rendered possible. It is for this reason that the Boand is expected to act, not in the formal manner in which a court conducts its procoedinges, but as any board of conciliation....

The Board will have performed its duties to the greater satisfaction of the public if it brings about an adjustment without finding it necessary to report at length with recommendations as to what should be done. ... It is only where they are unable to get the matter adjustod ... that they will be obliged to make recommendations in view of the attitude of the perties.

This was precisely what the boards did in fact."

The IDIA differed from its predecessors in two important ways. First, it applied to the full range of developmental industries listed above," not merely to railways. Second, it prohibited strikes and lockouts in those industries until a board had

"King Diary, 1, 2, and 3 January 1907, NAC, MG 26, J 13; Notes and Memoranda, King pepers, NAC, MG 26, J 4, vol. 14, file 85, C9952-3. The notes also state (at C9940), “...the Board is apt to do its most effective work to the degree with which it dispenses with urnecessary formalities and conducts its investigation in a manner similar to the manner in which the Deputy Minister of Labour has conducted his investigations when acting under the Conciliation Act." See also Lemieux's remarks on second reading, "It seems, Sir, that the fear of investigation is the beginning of wisdom for large corporations...", Canada, House of Commons, Debates, 14 February 1907, 3018. On the form of intervention in fact, see, Selekman, Postponing Strikes, 16, 103ff; Atherton, "Department of Labour," 220ff; Craven, 'AnImpartial Umpire', 297ff. Some commentators have suggested that this practice departed from the original intention. The archival recond makes clear that this was not the case.

${ }^{15}$ At 13. 
investigated the dispute and delivered its report. This served as a potent aid to conciliation: employees had to apply for a board if they wanted to strike legally. and conciliation would then take place in a calmer atmosphere, in theory more conducive to compromise. But of course the principal reason for the ban was simply that it postponed strikes. The objective of the conciliation policy was to prevent strikes. If one could do this during mediation, that alone was (from the government's perspective) a step in the right direction. ${ }^{6}$

Some commentators have interpreted the strike ban as a turning away from compromise and towards repression. At the very least, this conclusion deserves qualification. Violation of the ban exposed workers to real penalties, but prosecutions under the act were rare and never (until the last years of World War I) initiated by the government itself. Some workers were convicted on private prosecutions, and these were significant in particular disputes or regions. But by and large, violations (and there were many) went unpunished. No doubt many workers obeyed the law because they considered themselves law-abiding, because they wished to avoid the stigma of illegality, or because they feared prosecution, no matter how unlikely. This postponement of strikes could undermine a union's bargaining position, sapping enthusiasm and giving the employer time to prepare. But the strike ban's repression was largely dependent on its victims' compliance. As in other areas of labour policy, the government sought to structure employment relations by means other than open confrontation."

46 The suspension of strikes pending conciliation (at least by employces' forbearance) had often been advocated by labour experts and mediators and included in collective agreements. As an example, see Clute's Report, 364, 381-3, and his second report, Canada Sessional paper No. 146a, 1900, 7. A legislated strike ban had been proposed in the US in 1902, on the grounds that it would force parties to apply for conciliation, Final Report of the Industrial Commission, 859, 952.

Employers did not have to apply for a board prior to changing conditions, but the IDIA did stipulate that employers were to give thirty days notice of any change in wages and hours, and if application were made, conditions would then be frozen until the board's report. This meant that in theory, employees would be able to apply for a board prior to the implementation of changes, and thus trigger the wages and hours freeze.

"For the government's policy regarding prosecutions, see Selekman, Pastponing Strikes, 118-22; Atherton, "Department of Labour," 225ff. For examples of prosecutions, Ian McKay, "Strikes in the Maritimes, 1901-1914," Acadiensis, 13 (1983), 40-3; Labour Gazette, 8 (1907), 413, 8 (1908), 1094-7 (but the accused was not required to undergo sentence, Report of the Department of Labour for ... 1907-1908. Canadi Sessional paper No. 36, 69); Labour Gazette, 12 (1911), 595. Companies were suocessfully prosecuted for illegal lock-outs, Labour Gazette, 8 (1907), 689-90, 9 (1908), 57, 9 (1909), 1102-3. Very frequently, governmental officers dealt with illegal strikes through mediation. This was the case in one of the first strikes after the IDIA's adoption. King mediated a dispute in the Crow's Nest Pass, strenuously opposing the use of police reinforcements, claiming in his confidential record that "T heartily disapprove of the whole policy of coercion and intend to make it clear that the [DIA] has in view conciliation and nothing more:" King Diary, 19 April 1907 to 6 May 1907, NAC, MG 26, J 13, especially 21 and 26 April. 
Reviewing the legislative evolution, then, one is struck by the consistency of the government's strategy. From the time of Clute's investigation, the government sought a statutory framework which would inject a state-sponsored conciliator into a dispute, give that conciliator tools to get the parties talking, provide him with a way to extract concessions, and produce a settlement besed on compromise. Always, the essential goal was to prevent strikes through compromise. Legislative innovations were intended to perfect this kind of intervention, not supplant it. Some innovations, particularly the attribution of investigatory powers to conciliators, the involvement of the parties in the choice of board members, and the IDIA's strike ben, materially improved the govemment's ability to contain unrest, but there was always the possibility that at the end of the day conciliation would fail. Yet despite its preoccupation with the prevention of strikes, and despite frequent suggestions that it follow the example of New Zealand and Australia, Ottawa consistently refused to adopt the one form of intervention that promised the complete achievement of its goal - compulsory arbitration. The next section of this paper explains why the government declined the arbitral alternative.

\section{Reasons for the Rejection of Arbitration}

I WILL BEGIN BY examining the reasons expressed by the government itself, attempting to reconstruct the considerations which determined its opposition to compulsory arbitration. The govemment's own reasons are important, for they offer insights into the Canadian state's strategy for the management of industrial conflict and render more precise the relationship of this strategy to the Laurier government's larger economic vision. In Part 4 I will explore how the nature of the Canadian political economy created a structural preference for strategies based on accommodation.

One can begin by eliminating two criticisms of arbitration common today. The first, and most important, is that arbitration fails to achieve its principal aim - the prevention of strikes. Had this been clear at the time of the deliberations it would have been a potent objection, for the aim of the government's policy was industrial peace. But this was not clear. On the contrary, the evidence available suggested that arbitration was doing a good job of preventing strikes (although Canadian policymakers suspected that New Zealand's tranquility was due more to a rising market than to arbitration). At the very least, the jury was still out; arbitration could not be dismissed as ineffective.

"For the government's perception of strike prevention in New Zealand see, Canada, House of Commons, Debates, 6 May 1903, 2537-8; "Memo. re New Zealand Law," King papers, NAC, MG 26, J 4, vol. 14, file 83, C9432-3; the tentative conclusions in the briefing notes intended to justify rejection of arbitration, "Objections to Compulsory Arbitration," King pepers, NAC, MG 26, J 4, vol. 14, file 85, C10086ff, and the arguments following adoption of the IDIA, Report of the Department of Labour for ... 1907-1908, Canada Sessional paper No. 36, 1909, 50. For the actual situation, see, James Holt, Compulsory Arbitration in New Zealand: The First Forty Years (Auckland 1986), 35ff. 
The second criticism one can eliminate is arbitration's presumed "chilling effect" on collective bargaining. In today's industrial relations literature, arbitration is often criticized for stunting the normal course of bargaining: parties resist meaningful concessions in order to avoid prejudicing their case before the tribunal or to avoid making hard choices between competing priorities. Clearly, this consideration had no effect on the Laurier government's decision. During the period examined here, stable bargaining relationships were the exception, not the rule in Canada; many strikes were fought for recognition of the employees' bare entitlement to approach their employer collectively. Rather than seeing arbitration as stunting negotiations, most of those involved in the Canadian debate assumed that arbitration would encourage bargaining, because it would limit the employers' power to act unilaterally.

One can also dismiss a consideration which was raised at the time, but which appears to have been used only to excuse inaction - the argument that arbitration was outside the legislative jurisdiction of the federal parliament. This assertion was advanced during House of Commons debate on The Conciliation Act in 1900 and The Railway Labour Disputes Act in 1903, on both occasions to justify the government's failure to propose arbitration. But while the constitutional division of powers may have prevented the creation of an economy-wide arbitration scheme (although even this was uncertain), it definitely did not stop the government from imposing arbitration in areas of undisputed federal jurisdiction. This precise point was made by the labour member, Arthur Puttee, in the 1900 debate, and was the approach adopted by the government itself in the Fair Wages Resolution of 1900 (which sought to control wages paid on work done under government contracts), King's suggestions to Draper regarding the discussion of arbitration in the 1901 TLC executive report (arbitration in enterprises performing government contracts or benefiting from public bonuses), the scope of the 1902 arbitration bill (limited to railways), and the restriction of the IDIA itself after the decision of the Judicial Committee of the Privy Council in Toronto Electric Commissioners v. Snider [1925] A.C. 396. Indeed, the constitutional argument appears rarely in the papers of King or his department. It certainly was not treated as a peremptory objection. ${ }^{49}$

The chief reasons for the government's decision seem to be those used in the labour department's annual report of 1903 to explain the abandonment of the 1902 bill, and repeated in more graphic terms by labour minister Rodolphe Lemieux (on King's instructions) in the debate on second reading of the IDIA. On the latter occasion, Lemieux discussed the impracticable nature of arbitration as follows:

The government did stress the problems of enforcing arbitral awards but this was directed more to the invidious nature of enforcement than its impossibility (see below).

${ }^{49}$ Cansda, House of Commons, Debates, 6 July 1900, 9369-70, 9389, 6 May 1903, 2572; King Diary, 15 August 1901, NAC, MG 26, J 13; S.C. 1925, c. 14; "Objections to Compulsory Artitration," King papers, NAC, MG 26, J 4, vol. 14, file 85, C10086ff. For the Fair Wages Resolution, see, Craven, 'An Impartial Umpire', 191-3. 
In Cenada, suppoee that a compulsory arbitration bourd existed; an employee is condernned to eccept the wages fixed by that boand, the sheriff will enforce the decision of the borrd. the workmen will be soldiered by the force of the bayonet 10 work, but would any one believe that the work he will perform will be satisfactory to the employer? Take the reverse. An employer may be forced to pay a certain rate of wages; he will abide by the decision of the court, by the legal process, by the force of bayonets, but what will be the result - one of two things; either that the employer will adulterate the goods which he protuces or he will form a huge combination and control the purchasing power of the country, because if this law says that the employee shall be paid such a rate of wages and that the employer, on the other hand, shall pay such a rate of wages, the law does not say what will be the purchasing power of the community.

Two main considerations emerge from this comment: 1) the difficulty any govemment would have forcing employees to comply with an arbitral award; and 2) incompatibility between the judicial determination of wages and the operation of market forces. I will deal with each in turn.

Lemieux's first point purports to focus upon the quality of work one could expect from a coenced employee. Indeed, this was the standard justification given by courts for refusing to compel the performance of employment contracts. From the context of Lemieux's remarks and his allusion to bayonets, however, one suspects that the government's real concern was that it would be placed in the position of wielding those bayonets. Bayonets were a significant component of tum-of-the-century labour relations. In large strikes the militia was frequently summoned, ostensibly to control unrest. But the Laurier Liberals were uneasy about the public perception of this expedient. The language used to call out the troops emphasized that the sole purpose was to prevent civil disorder (although disorder might be defined broadly when it suited the authorities' purpose). And although the power to summon the militia was conferred by federal statute (and at times the government participated covertly in the militia's deployment), Ottawa was careful to distance itself, in public, from the exercise of that power. It repeatedly stressed that it did not summon the militia; local authorities did, acting in complete autonomy. The government professed extreme reluctance to assume the cost of military aid to the civil power, insisting that this was a local responsibility."

${ }^{50}$ Canada, House of Commons, Debates, 14 February 1907, 3030. Report of the Department of Labour for the year ending June 30, 1903. Canada Sessional paper No. 36, 1904, 59: "The difficulties besetting the enforcement of awards, and the liability of error arising in the judicial determination of relations which, in the interests of the parties and the business community must ultimately be determined by economic forces, appeared to be the strongest arguments urged against the principle of the [1902 arbitration bill] ..."

${ }^{51}$ Desmond Morton, "Aid to the Civil Power: The Canadian Militia in Support of Social Order, 1867-1914," Canadian Historical Review, 51 (1970), 407-25; Jean Pariseau, "Forces armées et maintien de l'ordre au Canada, 1867-1967: un siècle d'aide au pouvoir civil," thèse de doctorat, Université Paul Valéry III, Montpellier 1981. For Laurier's involvement in dispatching the militia, see, S.N. Parent to Laurier, 7 May 1902, S.N. Parent to Laurier, 9 
Ottawa acted with such discretion in order to avoid appearing to side with cmployers in disputes. It did not want to become a target for the wrath of striking workers, but wished to stand above the parties' conflict, purporting to represent the nation as a whole. Lemieux's remarks during the introduction of the IDIA suggested how the "welfare of the people and the unity of the nation" - indeed the authority of the state itself - could be damaged by large-scale industrial unrest. The role of the militia figured prominently:

The troops are callod out, bitterness and class hatred is created and we find that after a labour agitation, the country resembles a house divided against itself. The duties and obligations of citizenship are sometimes forgotten and the supreme authority of the State is ignored.

In the use of the militia, as in other labour matters, the wise course of government was (as King had noted six years earlier) to "evade rather than combat to save strife." ${ }^{\text {s2 }}$

The same insight informed the decision on arbitration. As Lemieux's reference to bayonets suggested, the enforcement of arbitral awards posed the same danger to the state's claim of neutrality. Arbitration was not, for the government, a means to achieve substantial changes in working conditions. It was a way to avoid strikes - to obtain results similar to those obtained by conflict, but without the social cost. Under those conditions, it was inevitable that sooner or later workers would be dissatisfied with an award. They would strike, and the state would be called upon to enforce the law. When this occurred, the government would not be able to hide behind the arbitrator. No matter how much it protested that it was merely implementing an independent decision, it would be the one holding the bayonets. If workers considered the arbitrator's award to be unjust, Ottawa would be blamed for enforcing an unjust award. If the government persisted, it would be drawn inexorably into apparent identification with the interests of employers. Faced with this prospect, the government drew back.

The government's awareness of the pitfalls of arbitration was not so much the product of intellectual reflection as of caution gained through the experience of previous disputes. Two examples show the way in which these lessons were learned. In the winter of 1900-01, Archbishop Bégin arbitrated a dispute involving boot and shoe workers in Quebec, the parties agreeing to be bound by Bégin's decision. The award stunned the employees: it required changes to the union's constitution and imposed a system of conciliation boards for seuling future dis-

May 1902, Laurier papers, NAC, Reel C-793, 64950, 64980-1. Another example of the govermment maintaining troops at apparent arms length is the 1903 Montreal longshoremen's strike, Laurier to James Cochrane, 5 May 1903, H. \& A. Allen et al. to Laurier. 7 May 1903, Laurier papers, NAC, Reel C-800, 72847, 72940-3, 72944.

${ }^{52}$ Canada, House of Commons, Debates, 14 February 1907, 3013; King Diary, 14 August 1901, NAC, MG 26, J 13. A similar rationale was probably responsible for the govemment's refusal to initiate prosecutions under the IDIA strike ban. 
putes. The union refused to comply, claiming that Bégin had overstepped his mandate. Throughout that year, the dispute over implementation of the awand dragged on. Then in December 1901, although the government had not participated in the arbitration, the employees appealed to the labour department for relief. The department's first reaction was to avoid the issue, arguing that it had not been a party to the arbitration, that it had no authentic information on the matter, and that it had not been consulted formally. The employees appealed once more and Mulock and King took up the matter with Laurier. Mulock was clearly of the opinion that Begin had gone too far, but he also realized that the existence of the award would make departmental intervention very difficult. "With such a disturbing factor [the Archbishop's attitude]," he wrote, "I doubt if the Department would be able to adjust the differences." A cautious Laurier, all-t00-acquainted with the dangers of confronting the church in Quebec, would not even admit that the religious authorities had overstepped their bounds. The government took no action. Clearly, the church's unique role had complicated the issue, and the government's lack of participation in the original reference enabled it to evade responsibility with some ease. But the govemment must have realized how easily arbitration could lead to demands for direct governmental action..$^{\text {st }}$

There was an indication one month later that it had leamed this lesson. A Quebec shipper had demanded that his employees absorb wage reductions to bring them into line with Montreal workers. He attempted to enlist the government's help. Mulock, in a letter to Laurier, suggested that the government should not propose arbitration; if it did, the men might well hold the govemment responsible for the resulting reduction. Instead, Mulock advised, Laurier should,

through some trusty and confidential friend in Queboc make known to the working men Mr. Harling's [the shipper's] apparent determination either to abandon Queboc or bring in laborers from outside the City and to lock out the present men, and otherwise impress upon these men the necessity for their coming to an agroement with Mr. Harling ... By some such method as this an agreement might be brought about, and if not the men would at least be more favourably inclined towards a settlement of the troubles by the Labour Department.

Thus, the government's first motive for rejecting arbitration was its desine to maintain a posture of neutrality in labour conflicts. This was sometimes little more than a posture: the govemment did have its sympathies. Indeed, as a number of the above examples show, on occasion it acted covertly to achieve its desired outcomes.

${ }^{53}$ Harper to Arthur Marois, 5 December 1901, Laurier papers, NAC, Reel C-791, 62293-5; Mulock to Laurier, 25 February 1902, Ed. Barry to Mulock, 13 February 1902, Laurier pepers, NAC, Reel C-792, 63220-2, 63223-9; King Diary, 10 March 1902, NAC, MG 26, J 13; Jacques Rouillard, Les syndicats nationaux au Québec de 1900 à 1930 (Quebec 1979), 161-70.

${ }^{34}$ Mulock to Laurier, 22 April 1901 [wrong date; it should read 1902], Laurier papers, NAC, Reel C-785, 55602-5. 


\section{LABOUR/LE TRAVAIL}

I argued above that worker dissatisfaction would have been inevitable, because the government did not consider arbitration to be a means of improving wages and working conditions. This brings us to the second of Lemieux's reasons for rejecting arbitration: the Laurier Liberals' deference to the outcomes achieved through the use of the parties' bargaining power.

The government wished to limit the economic and social disnuption caused by strikes, but it did not seek to change the substantive employment relationship. To the extent that the government's intervention involved some degree of union recognition or produced more generous settlements than an employer would have agreed to on its own, conciliation did influence substantive outcomes in employees' favour. But from the government's perspective this was incidental. Its purpose was to tame the exercise of economic power, not displace it. Its goal was to reproduce the kinds of results that an unconstrained ordering would have generated, but without the disruption of strikes.

This deference to the order produced by private decision-making was apparent in many of the government's criticisms of arbitration. In 1901, for example, King wrote in his diary:

Most men who consider \& advise [arbitration], see only the seeming immediate effect upon stoppage of strikes, they fail to see that a strike may after all bring greater good that [sic] its prevention. ... No judge unless he be an economic divinity could regulate rightly wages in any trade of importance for 1 year.

King seldom had anything good to say about strikes, but his skepticism of the ability of arbitration to serve as a substitute for economic forces is representative enough. At the time of adopting the IDIA, for example, the government relied upon two arguments to suggest why arbitration might work in New Zealand and Australia but could not work in Canada. Both assented that the specific characteristics of the Canadian economy meant that Canada could less afford to ignore the ordering produced by economic might. In the first of these arguments, Canada was portrayed as operating in a highly-competitive international environment (especially due to its proximity to the United States); New Zealand, Lemieux claimed (taking his lines from King), was "a non-competitive country." In the second, Canada's immense diversity was emphasized, a diversity requiring the adaptation of employment relations to local conditions, making the standardization of employment terms highly undesirable. These arguments might not have been very convincing in distinguishing Canada from Britain's southern dominions, but they do reveal the government's desire to subordinate labour policy to economic demands. They constitute the refined and respectable version of the opinion King expressed while conciliating the 1905 Western Fuel Co. dispute:

I pointed out [to the employees] however hard the fact might be it was nevertheless true that in matters of this kind one could only consider the ethical side of the question in the light of 
conditions as they are, that I had always found working men ready to ask themselves the question 'is this right', I had found capitalists ask themselves the question 'does it pay' and that before the question of right could be determinded [sic] in telling the men who were froe to put their capital where ever they wished transferred [sic] it from one business to another. the question of 'does it pay' would be one which would be necessary to consider at all times...

It would be wrong to equate this invocation of economic forces with devotion to the market, however - at least the kind of devotion now familiar in neoclassical economics. The Laurier govemment was not arguing for a general policy of laissez-faire, in which an unconstrained market would serve as the ultimate judge of efficiency. Indeed, the government's developmental initiatives involved a conscious attempt to direct market forces, to promote economic activity through vigorous state action. It deferred not to the market as such, but rather to the private ownership and deployment of capital, a condition seen as fundamental to vigorous conomic growth. Private property was valued not subsidiarily - becsuse a multitude of transactions by thousands of atomized individuals produced the most efficient outcomes - but for its own inherent virtues - because it permitted the full expression of individual initiative, the driving force of all creative economic activity. The central objective of government was not, then, to act as night-watchman, guarding the integrity of autonomous markets, but actively to serve "progress": to promote conditions conducive to the profitable deployment of private capital. Deference to the private ordering of economic relations was part and parcel of the specific character of the Laurier Liberals' developmental ethic - an ethic in which the driving force was private action. ${ }^{56}$

This deference to economic forces supported the choice of compromise over arbitration, for only if the employers voluntarily agreed would settlements accommodate the individualism of a dynamic economy. Clute summarized the relationship of conciliation to the demands of property in the 1899 Kootenay dispute:

The importance of allaying the distrust of investors was emphasized by all the leading managers, and by many other prominent men. This in my opinion can beat be done by a satisfactory and permanent settlement; not one that evidences the triumph of the unions, or

${ }^{55}$ King Diary, 12 January 1901, NAC, MG 26, J 13; Canada, House of Commons, Debates, 14 February 1907, 3029-30, Memorandum regarding the 1905 Western Fuel Co. dispute, King papers, NAC, MG 26, J 4, vol. 13, file 82, C9354-5.

The conception of progress and the primacy of property in Canadian liberalism are drawn from Fernande Roy's fine study, Progrès, harmonie, liberte: le libtralisme des milieux d' affaires francophones de Montréal au tournans du siècle (Montreal 1988). This vision was also influential in the formation of the government's policy on a second transcontinental railway. Jeremy Webber, "A Liberal Economy: Ideology and Govemment Ownership in the Grand Trunk Pacific Railway Debate, 1903-1904," unpublished paper, 1987. Indeed, it was more evident in the formation of the railway policy because there was greater disagreement within cabinet on that issue. 
the success of the owners, but a settlement to be arrived at by a consider ation of the question in dispute, on business principles, fair and reasonable to all parties...

Given a commitment to a private economy, conciliation was most likely to produce stable solutions because the process would be responsive to factors affecting the deployment of capital. The fundamental regard for the free disposal of property was also evident in King's fears, noted in his diary during the 1901 Rossland strike, shortly after a discussion with BC liberal-labour politician Smith Curtis (who had argued for compulsory arbitration and the labour reforms already adopted by that province):

All of Canada can learn from B.C., the province speaks a note of waming in the strongest terms against the dangers of labour democracy. Industry will be fettered, the source of wages \& wealth left undeveloped, if change does not come. Where men without a stake rule those that have everything to lose, or at least risk, the alarm is great.

That comment was not meant for public consumption. In public statements, the emphasis on property was downplayed (although it remained implicit in the assumption that development meant the expansion of privately-owned capital). Indeed, when the emphasis on property was muted, the invocation of an expansive and energetic individualism could include labour, thereby directing attention away from class differences toward a vision of individual equality. Mulock used such an argument against arbitration in 1903. "I believe," he opined, "that in this country where there is such a feeling in favour of freedom and manhood, the working classes would resent anything in the nature of the legal compulsion which is the feature of the New Zealand Act." This comment also appealed to a current in labour's discourse, evoking the notion of working-class independence which had been so influential in 19th-century trade unionism. By the time of this debate, that discourse was passing out of favour in labour circles. Indeed the government's language too was changing, replacing the focus on independent producers with one that championed the interests of the great consuming public (as we have already seen in King's invocation of public inconvenience, rather than the drive for

${ }^{7}$ Commission, Report, 390; King Diary, 18 and 19 November 1901, NAC, MG 26, J 13; King to Mulock, 18 November 1901, King papers, NAC, MG 26, J 1, vol. 3, 2557.

The deference to property was not absolute. The main actors within the Laurier government certainly believed that there could be "abuses" of priv ate power. It was willing to take limited legislative action to curb these abuses (for example, the Fair Wages Resolution). But this action was sparing indeed, designed to leave the private economy's essence intact. On one occasion King replied to Smith Curtis' proposals of arbitration as follows: "I let him see that I did not favour this tendency, \& was inclined to feel that it were better to leave industry more alone, save in laying down rules \& restrictions against unfair play, \& also subjecting it to the influence of public opinion where this could be focused thro' a Department or other means as e.g. in Conciliation." NAC, King papers, Diary, MG 26, J 13, 11 January 1901. 
development, as the justification for state intervention). In either form, the individualistic emphasis served to tum attention away from class confrontation and toward a conception of labour disputes as bargaining sessions specific to a particular enterprise. This served as an important foundation for the state's claim of neutrality. for the government could purport to intervene on behalf of the public - the great mass of workers, employers, farmers, and shopkeepers not directly involved in the dispute."

Thus, the government's conception of economic progress and the primacy of property contributed to its labour policy in three ways: it provided the developmental orientation which lay behind the desire to prevent strikes in the first place; it was the reason for the government's strong preference for leaving the deployment of capital in private hands; and it advanced a definition of labour unrest which obscured class conflict and supported the government's claim to neutrality.

\section{Arbitration and Class Structure}

UNTIL NOW I HAVE ADOPTED the government's perspective on conciliation and arbitration, but of course, the government did not formulate this position in a vacuum, unperturbed by material pressures. A number of those contextual factors have already been alluded to. Here I wish to address them directly.

By the time the government came to reject arbitration, its choice was straightforward. Arbitration's traditional supporters - organized labour - had never possessed sufficient political clout to compel the adoption of arbitration at the federal level, and by 1902, labour itself was divided on the question: the TLC removed arbitration from its platform in that year, and when consulted on the 1902 bill, the leadership of the railway unions opposed the measure. For their part, businessmen were either opposed to arbitration or, at best, very cautious supporters. The great majority of businessmen shared the government's preference for permitting property owners (themselves) to manage their enterprises as they saw fit, with a minimum of governmental control. Even the few that supported arbitration did so only in the most essential of industries, often industries upon whose continued operation their own businesses depended. Faced with the collapse of labour's support and the continued ambivalence (or outright opposition) of employers, the government could safely let the matter drop. Indeed, it would have taken exceptional boldness to proceed.

I do not intend to discuss labour and capital's positions on arbitration in detail. Labour's support and eventual rejection of arbitration have been extensively

\footnotetext{
${ }^{35}$ Canada, House of Commons, Debates, 3 April 1903, 953. For Canadian examples of the tradition of working class independence, see, McKay, "Wisdom, Wile or War;" Craig Heron, "Labourism and the Canadian Working Class," LabourlLe Travail, 13 (1984), 45-76; Canada, House of Commons, Debates, 10 December 1906, 794 (Ralph Smith).
} 
reviewed elsewhere. 99 In particular, I will not examine the steps which led to the AFL taking control of the TLC at the latter's 1902 Berlin convention and the consequent deletion of arbitration from the TLC's platform. That event certainly had a major impact on the timing and character of Canadian labour's renunciation of arbitration, but it is likely that even without the AFL's coup labour would have rejected the policy. Indeed, the only unions confronted with a concrete proposal for arbitration - the railway running trades - were not AFL affiliates, yet they too opposed the measure. There was good reason for their reticence, reason which went beyond the influence of Gomperite ideology. Comparison to those jurisdictions which adopted arbitration is instructive.

The jurisdictions that embraced arbitration (at least those which served as precedents in the Canadian debate), all did so in response to political pressure from labour, pressure occurring in circumstances where labour was economically weak but politically strong. In each case, labour had recently undertaken major strike action, only to be defeated. Significant solidarity remained, however - solidarity transcending the level of the firm to embrace a substantial section of the workforce. This brised but extensive solidarity, combined with disillusionment with the fruits of economic struggle, provided a strong basis for labour's "political tum." Having failed to achieve justice by economic means, workers sought to use state power to vindicate their conception of right. The outcome was the demand for compulsory arbitration.

In each jurisdiction where this demand was successful, labour won because the configuration of political forces had made it a potent ally to the governing party. In Nova Scotia, the Provincial Workmen's Association, following industrial defeat, was courted by the provincial Liberals, who at that time were attempting to undermine the Conservative bastion in the coalfields. The result was, among other things, The Mines Arbitration Act of 1888. In New Zealand and New South Wales, the demand for arbitration emerged out of the debacle of the maritime strike of 1890. In the first of these colonies, the Liberal Party sought to take advantage of working-class disaffection by entering an electoral alliance with the trade unions, pursuing objectives of interest to labour. In Australia, the unions turned away from the old parties, nominating their own candidates. In New South Wales these candidates attracted enough support to become an essential partner in governing coalitions. As such, they were able to obtain economy-wide arbitration laws. ${ }^{\infty}$

${ }^{59}$ Forsey, Trade Unions in Canada, 442-4 (and elsewhere for local unions); Gregory S. Kealey and Bry an D. Palmer, Dreaming of What Might Be:The Knights of Labor in Ontario, 1880.1900 (Toronto 1987), 330 ff; McKay, "Wisdom, Wile or War;" Mouat, "Genesis;" Babcock, Gompers in Canada, 93-4; Craven, 'An Impartial Umpire', 142-9.

${ }^{60}$ McKay, "Wisdom. Wile or War;" James Holt, "The Political Origins of Compulsory Arbitration in New Zealand: A Comparison with Great Britain," New Zealand Journal of History, 10 (1976), 99; Holt, The First Forty Years, 15-30; Robin Gollan, Radical and Working Class Politics: A Study of Eastern Australia, 1850-1910 (Kingsgrove, NSW 1960), 
In turn-of-the-century Canada, the relationship between labour's economic and political strength was quite the reverse. Many unions (especially in the industries of greatest concern to the government) were finding that they had some economic muscle, at least within their particular sectors. At the same time, labour was weak electorally. The Canadian working class did not have the same political cohesion (on a national scale) as the miners of Nova Scotia or the workers of eastern Australia and New Zealand. The reasons for the failure of labour political action in Canada have long been debated. It now seems clear that it cannot be ascribed to regional variations in worker militancy; recent historical work suggests that variations in militancy simpliciter - the willingness to engage in industrial action to better one's working conditions - were not as great as were once assumed. ${ }^{61}$ Nevertheless, one suspects that marked regional variations in the industrial base,

128-50, 175-89, 203-4; John Rickand, Class and Politics: New South Wales, Victoria and the Earty Commonweath, 1890-1910 (Canberra 1976), 7-80, 121-57; S.F. Mecintyre, "Labour, Capital and Arbitration 1890-1920," in Brian W. Head, ed., State and Economy in Australia (Melbourne 1983), 98-114.

In recent years, some Australian historians have challenged the traditional argument that arbitration was enactod at the initiative of labour. They draw attention to the leading role of liberal politicians in advocating arbitration, and to the opposition of some trade unionists to arbitration. See, for example, Ray Markey. "Trade unions, the Labor Party and the introduction of arbitration in New South Wales and the Commonwealth," and Stuart Macintyre, "Neither capital nor labour: the politics of the establishment of arbitration," both in Stuart Macintyre and Richard Mitchell, eds., Foundations of Arbitration:The Origins and Effects of State Compulsory Arbitration 1890-1914 (Melbourne 1989), 156-77 and 178-200. These contributions establish that arbitration's adoption was not the result of a purely class-based politics: arbitration was justified in terms of its benefits for society as a whole - not just one class - and its chief advocates were a coalition of advanced liberals and non-socialist labour leaders. But they do not undermine the conclusion that strong support from labour was essential to the adoption of an arbitration regime with toeth, nor that that support was informed by labour's experience of industrial conflict. Indeed, their evidence confirms those hypotheses.

Legislative reforms respecting labour are always the result of a tug-of-war between conflicting interests, not the dictation of one, and their ultimate form represents a mediation between those interests. The nature of that mediation is affected by the economic clouth solidarity, and political positioning of the relevant actors. In the Australian case, labour's political turn and substantial influence within the legislative arena were essential to the outcome.

${ }^{61}$ See, Bryan D. Palmer and Craig Heron. "Through the Prism of the Strike: Industrial Conflict in Southern Ontario, 1901-14," Canadian Historical Review, 58 (1977), 423-58; Nolan Reilly. "The General Strike in Amhersh, Nova Scotia, 1919," Acadiensis, 9 (1980), 56-77; McKay, "Strikes;" Gregory S. Kealey, "1919: The Canadian Labour Revolt," Labour/Le Travail 13 (1984), 11-44; Bryan D. Palmer, "Labour Protest and Organization in Nineteenth-Century Canada, 1820-1890," Labour/Le Travail, 20 (1987), 61-83; Douglas Cruikshank and Gregory S. Kealey, "Strikes in Canada, 1891-1950," Labour/Le Travail, 20 (1987), 85-145. 
the organization of the work process, and therefore the concrete experience of workers might go some way towards explaining the weakness of independent labour politics at the national level. Strong labourite traditions in other countries have often emerged in the wake of shared industrial struggles of national dimension. This was, for example, the case in Australia, where the maritime strike stimulated the development of a viable labour party. ${ }^{6}$

Such an economy-wide struggle did not occur in Canada until the closing years of World War I, and indeed it is hard to imagine how, before that time, common industrial action could have been waged at the national level. The Australian economy of the early 1890 s presented much less diversity and much greater integration. Each of the eastem colonies possessed a major port, which served as a mercantile centre for a large agricultural hinterland. Sheep-farming, an agricultural pursuit peculiarly susceptible to unionization, dominated that hinterland. Under those conditions, a dispute centering on the shearing and transportation of

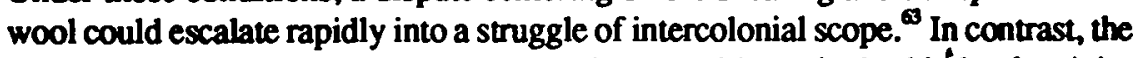
structure of the Canadian economy was diverse, with particular kinds of activity regionally concentrated. Coal mining occurred at the Dominion's two extremities: Nova Scotia on the one hand, and the Vancouver Island and Lethbridge-Crow's Nest Pass regions on the other. Metal mines were dispersed, chiefly across northern Ontario and Quebec and southeastern BC. Manufacturing dominated southem Ontario and Quebec. In rural areas, a host of unorganized farm workers participated in a variety of activities aimed at different external and internal markets. And while the government was actively trying to promote the integration of a Canadian national economy, no chain of production and distribution had anything like the economy-wide significance possessed by the processing and export of wool in the Australian context. ${ }^{a}$ The chief candidate for such a role would have been wheat, but not only were the producers of this commodity either small property-owners or unorganized labourers, but the functions associated with handling wheat were regionally concentrated, hardly touching important centres of trade union activity. Given this regional diversity, the practical coordination of economic action would have been difficult. And where were the common work experiences (at the national level) which give substance to solidarity? Recent studies of labour relations in individual firms or industries have emphasized how different occupational structures and even the firm's position in the product market shape worker organization. ${ }^{\text {so }}$ On the national level in Canada such diversity was magnified, with different

${ }^{\circ}$ Gollan, Radical Politics, 128-50; Rickard, Class and Politics, 38-63.
${ }^{\infty}$ Rickard, Class and Politics, 7-37.

It is instructive that in the eastern Australian colony possessing the greatest economic diversity - Victoria - independent labour politics had the least success in displacing the old-line parties. See, Rickard, Class and Politics, 43-6, 85-120.

${ }^{65}$ See, for example, the collection of essays in Craig Heron and Robert Storey, eds., On the Job: Confronting the Labour Process in Canada (Kingston 1986); Jacques Ferland, "Syn- 
petverns of industrial organization - different forms of work experience concentrated in specific sections of the country. Although general feelings of class sympathy crossed these boundaries, the raw material of worting alliances was largely absent.

In the absence of strong economic challenges perceived to pit class against class at the national level (challenges which did emerge, however briefly, during World War I), other allegiances took precedence. There were many competing allegiances. The government's developmental policy tried to unite Canadians of all classes behind the goal of economic expansion. Employers and their associations attempled to foster (with varying degrees of success) loyalty to the firm or industry, trying to develop coalitions around, for example, issues of tariff protection or froe trade. Ethnic, linguistic, regional, and religious identifications dominated much of Canadian political discourse. It was these divisions and these loyalities, not those of economic class, that held prominence in national politics. In some provinces, working-class solidarity could be transformed into political strength and labour's concerns could be pushed to the top of the agenda. In the late 19th century, organized labour did wield considerable influence in BC and Nova Scotia. But on a national scale the labour vote, though periodically wooed, did not have the cohesion to compel reforms as far-reaching as arbitration.

This relative weakness not only prevented labour from insisting upon the adoption of arbitration; in the end it made that policy much less auractive to labour. Labour supported arbitration as a way of bringing justice to the workplace. Arbitration would create "a new province for law and order," where the employers" power would be constrained by considerations of right. But although both parties might speak of industrial justice as though it were a neutral standand, there were competing conceptions of what justice entailed - conceptions which were joined to fundamental oppositions of economic interest. As workers eventually came to realize, the definition of justice that would prevail under arbitration depended upon who would do the judging. In the abstract, workers might demand that institutions should be created to dispense an undifferentiated justice. But when faced with a concrete proposal, they were forced to confront the prospect that judges might not share their understanding of the term. In turn-of-the-century Canada, given labour's political weakness, they could have no assurance that judges would adopt their view. They therefore abandoned arbitration, choosing to trust their emerging economic power.

dicalisme 'parcellaire' et syndicalisme 'collectif': une interprétation socio-technique des conflits ouvriers dans deux industries québécoises, 1880-1914," Labour/Le Travailh 19 (1987), 49-88; Craig Heron, Working in Steel: The Early Years in Canada, 1883-1935 (Toronto 1988), 112-59; James R. Conley, "Frontier Labourers, Crafts in Crisis and the Western Labour Revolt: The Case of Vancouver, 1900-1919," Labour/LeTravail, 23 (1989), 9-37.

${ }^{66}$ See, Kealey, “1919.” 
One can see this dynamic at work in labour's reaction to the government's proposal for arbitration on the railways. At that time, Shaughnessy was in a position similar to that of New Zealand labour after 1890 - smarting from cconomic defeat. looking to secure his idea of justice through political means. At the same time the unions, possessing much less political clout, had won significant victories through strikes, finally managing to establish stable structures for bargaining. It was not surprising, then, that the unions should resist trusting their welfare to boands despite the traditional support of many of their members for arbitration. Precisely the aspects of arbitration that appealed to Shaughnessy could not have appealed to them. Although no other unions were presented with such a concrete choice, all but the weakest would clearly face similar considerations: given their inability to control the nomination of arbitrators, would their justice prevail?"

\footnotetext{
"A number of union criticisms of the 1902 bill focused on the constitution of the arbitration board although in submissions to the government this criticism was muted by the board's tripartite structure. Because the board was formed of nominees of each party, with (if the nominees failed to agree) the chair chosen by the government, any direct eccusation of bias had to attack the impartiality not only of the employer's nominee, but also of the government's. Union representatives naturally balked at this. Nevertheless, see the file of submissions received on the 1902 bill, especially the resolution of Lodge No. 519. Brotherhood of Railroad Trainmen (endorsed by a number of other labour organizations): Labour Records, NAC, RG 27, vol. 71, file 322.1(3). For the collective bargaining success of the brotherhoods prior to 1902, see J.H. Tuck, "Canadian Railways and the International Brotherhoods: Labour Organization in the Railway Running Trades in Canada, 1865-1914," PhD thesis, University of Westem Ontario, 1975, especially at $107 \mathrm{ff}$.

It follows that I disagree with the reasons for Canada's rejection of arbitration advanced in Richard Mitchell, "Solving the Great Social Problem of the Age: A Comparison of the Development of State Systems of Conciliation and Arbitration in Australia and Canada, 1870-1910," in Gregory S. Kealey and Greg Patmore, eds. Canadian and Ausralian Labow History: Towards a Comparative Perspective (Sydney 1990). Mitchell's andysis contains two serious flaws: 1) it exaggerates the Canadian govemment's commitment to arbitration; 2) it atributes labour's rejection of arbitration to the simple failure of Canadien legislation to recognize unions as the bargaining agent for employees. Canadian unions certainly would hrve preferred express recognition, but it is wrong to elevate this to a sine qua nom, without which unions would reject government initiatives. Recognition in turn-of-the-century Canada is best considered as a continuum, beginning with the employer's willingness to meet committees of its own employees, through meetings with committees containing non-employees, to meetings with union officers, and finally to various ways of institutionalizing the union's role within the enterprise. (See Webber, "Standards of Industrial Justice," 156ff.) While unions would prefer to be at the latter end of the continum, they might well accept lesser forms of recognition. Recognition of employee committees could, for example, amount to union recognition if the union had sufficient support to ensure that it formed the committee. The railway brotherhoods' concern ran deeper than the formality of recognition; they feared they might lose the benefit of their economic leverage and be compelled to accept the industrial justice of another class.
} 
Thus, the inability of Canadian labour to form strong alliances at the national level undermined its commitment to a national system of arbitration. But segmentation of the Canadian political economy not only sapped support for arbitration; it also created a structural bias in favour of govemmental strategies based on compromise.

Just as deep divisions made it difficult for labour to maintain cohesion on a national basis, the divisions of class, ethnicity,religion, industry, and region within the polity as a whole made it difficult for political parties to build strong movements expressly committed to pursuing one group's (or a limited number of groups') interests. Overtly championing certain sections of capital, for example, risked alienating farmers, labour, and those capitalists disadvantaged. Advocating the interests of farmers or workers generated similar risks. The government might well prefer the interests of one group (as the Laurier government did prefer owners of infrastructural industries and finance capital), but the ability to ect on this preference was mediated by the political necessity to appeal, especially in public discourse, to as many components of society as possible, to define objectives that obscured division and emphasized commonality, to aim for the grend coalition. It was this characteristic of the Canadian polity that pushed the government to portray itself as neutral, standing apart from the interests of the parties, serving as a voice for cohesion. Faced with this environment it was good strategy, then, to eschew a policy which would force it continually to choose, under public scrutiny, between competing notions of economic justice.

The genius of the drive to settle the West and expand the Canadian economy was that it appealed to a wide spectrum of Canadian society, purporting to unite all in the great national endeavour. The components of the policy were carefully adjusted to secure broad public support. Within that framework, the government adopted compatible means to manage industrial unrest - means which would help maintain industrial peace, while keeping intact the government's claim to act for all Canadians.

\section{Conclusion}

ONB CAN THEREFORE see with some precision how these strands worked together to form a coherent and remarkably-consistent labour policy.

The impetus behind the Laurier government's policy was the perceived need to prevent strikes in order to maintain the pace of economic development in Canada. The growth of industry and the settlement of the West were seen to depend on the continuous operation of certain key industries. The government's policy was designed, as far as possible, to satisfy this condition of prosperity. In Miliband's terms, the state was moved to intervene in labour disputes in order to assist the accumulation of capital.

Ralph Miliband, The State in Cepitalist Saciety (London 1973). 
Under the Laurier Liberals, this commitment to accumulation assumed a specific character, stemming from its developmental orientation. The support for accumulation was not merely implicit, it was express. And it was framed in such a way that it did not purport to take from other segments of society to benefit capital; rather, it was presented as the opening up of new territory, the creation of new wealth, producing benefits in which the whole of Canadian society would share. This form of accumulation would produce no losers, only winners. While it was the that certain private actors would be subsidized directly by the state, this did not mean that those actors would reap an unjustified windfall. For effective growth to occur, one had to rely on the dynamism of private initiative. The economic prosperity engendered by this dynamism would adequately repay the public's investment.

There were challenges to this version of how to build a country. There was, for example, considerable resentment against companies that benefited from exclusive franchises or captive markets. One thinks especially of western Canadian criticism of the CPR. In order to continue offering support to private industry, the government had to keep this dissatisfaction contained. This meant, at a basic level, ensuring that the parties' misconduct did not deprive the public of the benefits of continued service. Not only did strike prevention play a role in directly fostering accumulation, then, it also helped preserve the legitimacy of the developmental strategy.

This prevention of strikes could not take the form of mere suppression, however. Such an approach would have elicited a vigorous reaction from labour, a reaction which, if nothing else, would have disnupted the developmental strategy. But there also were positive reasons inherent in the structure of the Canadian polity for emphasizing neutrality and reconciliation in labour-management relations. The segmentation of Canadian society meant that there was insufficient support for such obviously-preferential intervention. The government had good reason to appear to be neutral, apparently working in an impartial manner to maintain society's cohesion.

The govemment rejected arbitration because it would have imperiled this jealously-guarded picture of neutrality. The government's sole reason for initiating intervention was to manage the process of dispute resolution. It had no interest in advancing workers' notion of justice. Indeed, it was suspicious of the Australasian legislation, wondering whether those statutes fell within that most reprehensible of categories to a liberal - "class legislation." the outcome of private ordering, as long as that ordering caused minimal disruption. At the same time, the government realized that if it made awards enforceable, it

${ }^{\infty}$ King Diary, 22 August 1901, NAC, MG 26, J 13; King to H.A. Harper, 24 August 1901, King papers, NAC, MG 26, J 1, vol. 3, 2382; "Canada's Autitude towards Labour," Harper papers, NAC, MG 30, A 28, vol. 2; "Objections to Compulsory Arbitration," King papers, NAC, MG 26, J 4, vol. 14, file 85, C10089. 
would inevitably have to choose - publicly - between conflicting forms of industrial justice. When employees rejected an award, it would have to decide whether to abandon the independence or constraining authority of the arbitration process, or use its coencive force in what employees considered to be the cause of injustice.

The answer, of course, was itself a compromise: get as much strike prevention as possible, but never publicly tie state power to one particular outcome. Push the parties towards compromise, but leave the final settlement to them alone. The structure of conciliation developed at the turn of the century and enshrined in the IDIA accomplished this admirably. When obeyed, the act prevented strikes until intervention had occurred. It injected a board containing the parties' own representatives into the dispute. It gave that board tools to get the parties talking and to extract concessions. Through persuasion, the board might even mudge an employer toward compliance with some conception of decent industrial conduct. But in the last analysis, the perties would decide the terms on which they would setule, terms which would reflect oconomic "conditions as they are." When presented with concrete proposals for arbitration, this too was the solution preferred by the leaders of organized labour. They docided it was better to depend on workers' emenging economic power than place their conditions of employment in the hands of judges of another class, over whom they had not control.

Thus was bom the policy of "compulsory conciliation," to be followed in time by "compulsory collective bargaining." The characteristics of labour policy identified in the arbitration debate have a familiar ring to students of today's labour law. Still the state claims neutrality. Still it promotes compromise, eschewing in normal times any concern with the content of agreements (beyond the establishment of certain minimal standards). When it does intervene more strongly (for example, to impose wage controls), it purports to do so by exception only, and always in the interest of society as a whole. And in the end, although the definition of public interest has changed with changes in Canada's economy, the government's handling of public-interest strikes continues to be marked by a fundamental tension between the desire for peace and the deference to consent.

My thanks to Paul Craven and especially to Chief Justice Alan B. Gold, who set me to work on the origins of Canada's conciliation policy in 1982 when he was Scholar in Residence at McGill's Faculty of Law. This paper is, in many ways, a product of that research. Any errors of interpretation remain my own. Research for this paper was funded in part by the SSHRC and the MCGill Faculty of Graduate Studies and Research. Previous versions were presented to the 1988 Australian Canadian Labour History Conference and the 1988-89 York University Advanced Research Seminar on Labow and the Law in the Commonwealth. 


\section{THE CANADIAN}

\section{HISTORICAL REVIEW}

Lively articles, comprehensive reviews, authoritative research, and a strong editorial policy have made The Canadian Fistorical Review the only national, quarterly journal covering the broad spectrum of Canada's history.

The CHR's appeal lies in the variety of the subjects addressed in its articles. Topics of interest range from Economics and Political history to Native and Legal history to Science and Labour history. In addition, informative reviews of historical writings, popular and scholarly and an extensive bibliography of recent writings in Canadian history make the CHR the one publication in the field that you should subscribe to.

Individual Subscription:

Institutional Subscription: $\$ 50.00$

Canadian subscribers please add 7\% GST.

GST Registration Number R108162330

U. S. and foreign subscribers please add $\$ 5.00$ for postage. CHR is also available through major subscription agencies.

Name

Address

City Province/State

Postal/Zip Code

Credit Card Number

Signature

Expiry Date

Mail your order to:

University of Toronto Press, Journals Department 5201 Dufferin Street

Downsview, Ontario, Canada M3H 6 T8 